\title{
Merkavahmystikken mellem tradition og innovation
}

\section{Øyvind Jørgensen}

\begin{abstract}
Aarhus
Indledning

Hensigten med nærværende artikel er at vise, hvorledes visse dele af jødedommen i talmudisk tid, sc. Merkavahmystikken, lod magi indgå i sin religiøse tilværelsesforståelse og placerede sig dermed på tærskelen til en teologi, der på væsentlige punkter afveg fra den traditionelle opfattelse. ${ }^{1}$ Dermed være imidlertid ikke sagt, at Merkavahmystikken gav afkald på den tradition, som den udsprang af. Der var snarere tale om en nyinterpretation af tankegods, som man i én eller anden forstand fandt brugbart til sit forehavende. Det skal dog understreges, at store dele af Merkavahmystikken udviser en traditionel gudsopfattelse med Gud som den oph $\varnothing j$ ede og almægtige skaber, hvor distancen mellem denne og mennesket er opretholdt. Men denne konception står som sagt ikke alene, idet der tillige eksisterer passager, hvis teologiske implikationer gør det vanskeligt at placere disse inden for rammen af et ortodokst - eller traditionelt - gudsbegreb. Der er tale om, at mennesket, in casu Merkavahmystikeren, via en særlig teologisk onomatologi og anvendelse af magi instrumentaliserede sit gudsbegreb i en sådan grad, at den føromtalte distance næppe lod sig opretholde.

Jeg vil, således som det er kommet til udtryk i det ovenstående, hævde, at der kan argumenteres for, at flere passager $\mathrm{i}$ kilderne med deres tydelige magiske islæt afspejler en tendens i retning mod en heterodoks eller innovativ teologi, og i denne sammenhæng vil jeg gøre gældende, at Gershom G. Scholem indtog et unuanceret standpunkt, når han gav udtryk for, at
\end{abstract}

The texts of Merkabah mysticism that have so far come to our knowledge also display what I have called an orthodox Jewish tendency, and are in no way heretical. By this I mean that although they expound some ideas of a highly mystical character, these texts adhere strictly to monotheistic concepts. (...) These mystical aspects, however, do not detract from the basic fact that the theology presented, or rather implied, here does not conflict with the biblical concept of God, ...2

\footnotetext{
${ }^{1}$ Litteraturen om magi er omfattende, og noget tilsvarende gælder for antallet af definitioner, der $\mathrm{i}$ tidens løb er blevet fremsat $i$ denne forbindelse. For en foreløbig orientering vil jeg henvise til min artikel i Religionsvidenskabeligt Tidsskrift, Nr. 29, 1996, 55-75.

${ }^{2}$ Scholem 1965, 10. Scholem er ikke alene om at repræsentere et noget problematisk syn på Merkavahmystikken. Han făr bl.a. følgeskab af Philip S. Alexander, som i en artikel giver udtryk for, at "Odeberg and Scholem are fully justified in regarding the Hekhaloth texts as basically 'orthodox'. They must certainly be judged to be such if measured by the simple yardstick of whether they are monotheistic and show due respect for Torah." - cf.
} 
Dersom man blot lader kriteriet for "ortodoksi" være et spørgsmål om, hvorvidt teksternes indhold "adhere strictly to monotheistic concepts", er der $\mathrm{i}$ mine øjne tale om en prokrustesseng, hvor talrige religiøse helhedskonceptioner/idéer i større eller mindre grad kan tilpasses. "Monoteisme" som sådan kan selvsagt ikke anvendes som eneste parameter $i$ en vurdering af Merkavahmystikkens placering i forhold til den traditionelle jødedom. Det er $\mathrm{i} \emptyset$ vrigt karakteristisk for Scholem, at han intet sted søger at give en udtømmende definition af det, som han kalder "ideas of a highly mystical character". ${ }^{3}$ Inden vi går videre, vil det være på sin plads at berøre de kronologiske og geografiske problemer, der er forbundet med Merkavahmystikken i dens formative fase for - derefter - at kaste et blik på dens forskningshistorie.

\section{Merkavahmystikken - kronologisk og geografisk}

Den tidlige jødiske mystik, således som den findes nedfældet i Hekhalotlitteraturen, lader sig på nuværende tidspunkt ikke bestemme eksakt med hensyn til et kronologisk endsige geografisk udgangspunkt. ${ }^{4}$ Udtrykket "Hekhalotlitteratur" dækker over en række forskellige skrifter, hvis historiske genesis fortaber sig i det dunkle - vi kender på nuværende tidspunkt således ikke navnene på forfatterne endsige redaktørerne. Med hensyn til traditionernes

Alexander 1977, 174. Problemet er just, at det ikke er tilstrækkeligt at anvende "the simple yardstick", dersom man vil unders $\emptyset$ ge denne problemstilling til bunds. Det bør dog pointeres, at det især må regnes til Scholems fortjeneste, at hele den jødiske mystik blev gjort salonfähig i den videnskabelige diskurs.

${ }^{3}$ Det ville føre for vidt - og tillige ligge uden for mit sigte med denne artikel - at komme med en større udredning af begrebet "mystik". Jeg vil imidlertid ikke afholde mig fra at fremsætte en definition: "Mystik er en - hyppigt ritualiseret - transliminal praksis af kortere eller længere varighed, ofte med et kommunikativt element, rettet mod en koncentreret - til tider auditiv - erfaring af enten en skuen/vision af (spectatio/visio mystica), eller en nærhed med (praesentia mystica), eller af en forening med (unio mystica), eller af en identifikation med (identificatio mystica) et metafysisk center (eller et aspekt af et sådant center), der almindeligvis er karakteristisk for den tradition, som den pågældende udøver befinder sig i." Som det fremgår af denne definition tager jeg afstand fra den hyppigt forekommende forestilling, at "mystik" udelukkende er kendetegnet ved en unio mystica-oplevelse alt efter tradition o.a. kan den mystiske erfaring naturligvis antage andre former.

${ }^{4}$ Med udtrykket "den tidlige jødiske mystik" sigtes der hér og i det følgende kronologisk til perioden 2. - 6. århundrede e.v.t. Jeg vil påpege, at vi også finder, hvad vi passende kunne kalde "mystiske spekulationer" over Guds trone, מבכבה, i Dødehavsteksterne - nærmere bestemt i manuskriptet $4 Q$ Serekh Shirot 'Olat ha-Shabbat fra 2. halvdel af 1. årh. f.v.t. Men eftersom der ikke er tale om, at vi hér har med en mystikorienteret "bevægelse" at gøre, der er kommet til udtryk i et tilsvarende litterært system, tillader jeg mig at betegne Merkavahmystikken som "tidlig jødisk mystik", - cf. John Strugnell, 318-345; Lawrence H. Schiffman, 15-47 samt David J. Halperin 1988, 49-55.

Følgende tekster anses af de fleste forskere for at udgøre en "hovedbestanddel" af Hekhalotlitteraturens korpus: Hekhalot Zutarti (היכלות זוטרתי), Hekhalot Rabbati (היכלוה רבתי), Ma'aseh Merkavah (מערות), Merkavah Rabbah (מרכבה רבה), Massekhet Hekhalot (ספחת היכלות) samt 3 Enok eller Sefer Hekhalot (דפרות) Iיכלות). Desuden medregnes de såkaldte Geniza-tekster T.-S. K 21.95 (i nærværende artikel betegnet med G) samt andre mindre fragmenter i Peter Schäfer (Hrsg.), Geniza-Fragmente zur Hekhalot-Literatur. Det skal understreges, at der ikke hersker konsensus vedrørende Hekhalotlitteraturens fulde omfang - der eksisterer med andre ord ikke en fastlagt "kánon". Med hensyn til anvendelsen af termini technici samt kildebetegnelser vil jeg henvise til min artikel "Om mystik, Hekhalotlitteraturen, og dens syn på forholdet mellem Gud og Metatron" $i$ Nordisk Judaistik, Vol. 17, 1996, 139, note 2. 
geografiske proveniens er der dog visse elementer, blandt andet de magiske, der kunne indicere, at Babylonien har spillet en væsentlig rolle $\mathrm{i}$ dén henséende, hvilket dog ikke udelukker en $\emptyset$ stlig mediterran/palæstinensisk faktor i Merkavahmystikkens formative fase. Det er i denne sammenhæng vigtigt at understrege, at der - i modsætning til, hvad visse forskere synes at mene - faktisk findes vidnesbyrd om en mystisk praksis i de palæstinensiske rabbinske kilder, der kan forbindes med Ezekiels tronvision i Tanakh. ${ }^{5}$ Tilsvarende må fund og tolkning af amuletter med magisk betydning i Palæstina i nogen grad siges at have flyttet det geografiske tyngdepunkt, idet materialet viser, at magi på disse breddegrader var en levende tradition fuldt ud på højde med den tilsvarende udbredelse og integration i Babylonien - $\mathrm{i}$ visse tilfælde kan man endog konstatere, at der har været tale om en påvirkning fra Palæstina mod øst. Jeg vil dog understrege, at det ikke er muligt at drage definitive konklusioner med hensyn til Hekhalotlitteraturens udspring på basis af disse fakta. På den anden side hersker der i mine øjne ikke den mindste tvivl om, at de arkæologiske opdagelser i Palæstina bør bevirke, at man anlægger et mere nuanceret syn på dette spørgsmål. ${ }^{6}$ Problemet er naturligvis af stor interesse, idet en lokalisation af udgangspunktet - såvel kronologisk som geografisk - ville bringe nogen klarhed over dunkle passager i litteraturen. Med de forbehold som man altid må tage, når man bevæger sig ud på rekonstruktionens tynde is, kan man vel tænke sig, at dele af Hekhalotlitteraturen på et tidspunkt er nået til Ægypten samt Nordafrika, idet vi fra Kairo er kommet i besiddelse af manuskripter, der for en dels vedkommende stammer fra perioden kort før 9. årh. frem til midten af 11. årh. Vi har tillige vidnesbyrd om, at jøderne i Marokko, nærmere bestemt Fez, kendte til disse traditioner. Dvs. at vi med en vis rimelighed kan sætte 1050 som en terminus ante quem for det tidspunkt, hvor hovedparten af denne del af litteraturen har foreligget i sin nuværende form. Det må tillige pointeres, at teksternes indbyrdes forhold til tider er meget komplicerede, hvilket - sammenholdt med deres i visse tilfælde fragmentariske tilstand - gør det vanskeligt at pege på ét centralt, gennemgående motiv. ${ }^{7}$ Med hensyn til Hekhalotlitteraturens sprog, hvor hebraisk og aramæisk må siges at være absolut

${ }^{5}$ Cf. min artikel i Nordisk Judaistik, Vol. 17, 1996, 139, note 1 vedrørende inspirationen fra Ezekiel. Eksempelvis mener David J. Halperin ikke, at disse (rabbinske) kilder giver et holdepunkt for forekomsten af denne mystik. Jeg mener imidlertid, at han tager fejl på dette punkt, idet bl.a. Arnold M. Goldberg har påvist eksistensen af en sådan praksis, - cf. Goldberg, 296.

\footnotetext{
${ }^{6}$ Naveh \& Shaked, 17-39. Samme gør gældende, at der i Dødehavsteksterne (4Q 510-511) findes hymner med apotropæisk indhold, der sandsynliggør, at der har været én eller anden form for magisk praksis til stede i kredsen(e) bag disse tekster. Michael D. Swartz argumenterer for, at én af teksterne i Hekhalotlitteraturen, sc. Ma'aseh Merkavah, afspejler "... a long process of evolution, from Palestine in the third or fourth centuries to Babylonia in the late Geonic period.", - cf. Swartz 1992, 220. Det skal understreges, at Swartz hovedsagelig baserer sin argumentation på litterære og stilistiske kriterier.
}

\footnotetext{
${ }^{7}$ Klaus Hermann siger i denne forbindelse, at "Die angeführten Beispiele dürften zur Genüge belegen, daß sich der Hekhalot-Literatur als ein äußerst komplexes und vielschichtiges literarisches Phänomen darstellt, das von vomherein den Forscher Gefahr laufen läßt, einen Aspekt (Aufstieg, śar ha-tora Thematik, Magie etc.) ins Zentrum der Merkavah-Tradition zu rücken und als Erklärungsmodell für das ganze Phänomen anzusehen.", cf. Hermann, 5. Jeg er enig med Hermann i dette, og mit forehavende er da ej heller at lade eksempelvis "magi" "ins Zentrum der Merkavah-Tradition zu rücken und ..."
} 
dominerende, anses det $\mathrm{i}$ vide kredse for ganske usandsynligt, at der skulle være tale om en oversættelse fra ét eller andet "originalsprog", f.eks. græsk eller koptisk, til de nuværende. Dette udelukker naturligvis ikke, at der forekommer ord eller vendinger af ikke-semitisk oprindelse (eksempelvis latinismer og græcismer), der så er blevet transskriberet til hebraisk/aramæisk i teksterne. ${ }^{8}$

Det ligger således i sagens natur, at problemet vedrørende Hekhalotlitteraturens historiske matrix, samt i særdeleshed tidsfæstelsen af indholdet, dvs. traditionerne, har optaget en forholdsvis stor plads $\mathrm{i}$ forskningshistorien.

\section{Merkavahmystikken - fra Graetz til Scholem}

Retrospektivt må man konstatere, at udforskningen af den jødiske mystik, hvad enten det drejer sig om Merkavahmystikken eller den senere Kabbalah, har været stedmoderligt behandlet indtil omkring midten af 1800-tallet. Dette beklagelige forhold udspringer til dels af de sparsomme kilder, der var til rådighed for datiden, samt den modvind som den jødiske oplysnings- og emancipationsbevægelse, Haskalah, skabte i slutningen af 1700-tallet i såvel Vest- som Østeuropa mod beskæftigelsen med mystik, idet denne interesse blev anset for at være en atavisme. En senere udløber af denne strømning fandt grobund i intellektuelle kredse, hvor man nu med en vis rationelt begrundet distance dyrkede "Wissenschaft des Judentums". Heinrich Graetz var således blandt de første, som beskæftigede sig mere udf $\varnothing$ rligt med Hekhalotlitteraturen i nogle artikler, der blev offentliggjort i Monatschrift für die Geschichte und Wissenschaft des Judenthums fra 1859. ${ }^{9}$ Han hævdede, at der var tale om tekster, der næppe kunne være forfattet samtidigt med Talmud, hvilket førte ham til at konkludere, at Hekhalotlitteraturen var post-islamisk - ja, den var endog blevet udsat for islamisk påvirkning. Andre søgte ligeledes at påvise en sådan indflydelse, og i denne sammenhæng bør Philip Bloch nævnes som repræsentant for det synspunkt, at optegnelsen over himmelsfærerne og det dermed forbundne himmelrejsefænomen skulle være udtryk for en påvirkning fra islam:

... die sieben Hallen mit ihrer Ausschmückung und die Himmelfahrten scheinen dem islamitischen Gedankenkreis entlehnt zu sein. ${ }^{10}$

Forestillingen om den islamiske påvirkning af Merkavahmystikken blev dog hurtigt genstand for kritik, og den blev tilbagevist af bl.a. Moses Gaster i 1893. ${ }^{11}$ Det var imidlertid først med Scholem og hans i sin tid banebrydende værker, at den jødiske mystik for alvor blev gjort

\footnotetext{
${ }^{8}$ Som eksempler kan blandt andet nævnes פמיליא (lat. familia - cf. § 20 , V 228) eller סנירורן (gr. ourí forsvarer - cf. § 76, V 228)

${ }^{9}$ Graetz, 67-78; 103-118 samt 140-152. Titlen på dette tidsskrift (jf. ovenstående) taler sit tydelige programmatiske sprog.

${ }^{10}$ Bloch, 69. Der sigtes til visse dele i den islamiske traditionslitteratur, Hadith, hvor Muhammads mystiske oplevelse, således som den er beskrevet i Quranen, Sure 17, blev tolket som en rejse til den syvende himmel.

${ }^{11}$ Gaster, 179-185 samt 213-230.
} 


\section{Øyvind Jørgensen}

til genstand for større og mere dybtgående undersøgelser (jf. ovenstående).

Scholems opmærksomhed var i denne forbindelse især rettet mod Hekhalot Rabbati $(H R)$ samt Hekhalot Zutarti (HZ), og han daterede førstnævnte til at være en redigeret tekst fra 5. 6. århundrede, hvorimod sidstnævnte- hævdede han - var den ældste i Hekhalotlitteraturen. ${ }^{12}$ Senere beklagede han, at han tilsyneladende ikke tog skridtet fuldt ud og var mere dristig i sin datering:

The truth of the matter is that in many respects I was not radical enough. I dated the oldest of these texts from the fourth and fifth centuries, although stating that they contained some material which was much older and which presented striking parallels to Gnostic teachings and practices. ${ }^{13}$

Dvs. at man ifølge Scholem snarere skal sætte 2. årh. e.v.t. som en terminus ante quem med henblik på en datering af traditionerne i $H Z$ - redaktionen af disse skulle så være foregået i 3.-4. årh. Som locus, a quo var han af den overbevisning, at Merkavahmystikken opstod i Palæstina og var centreret omkring elever af Rabbi Yohanan ben Zakkai. ${ }^{14}$ I Hekhalotlitteraturen finder man levn fra dengang gruppen (eller grupperne) stadigvæk var aktiv(e), hvilket i denne sammenhæng vil sige, at man - mere eller mindre hyppigt - havde mystiske erfaringer:

... we are dealing with organized groups which foster and hand down a certain tradition: with a school of mystics who are not prepared to reveal their secret knowledge, their "Gnosis", to the public. ${ }^{15}$

Som det fremgår af dette citat optog spørgsmålet om Merkavahmystikkens eventuelle udgangspunkt i gnosticismen ligeledes Scholem, og han konkluderede i denne forbindelse:

Originally we have here a Jewish variation on one of the chief preoccupations of the second and third century gnostics and hermetics: the ascent of the soul from the earth, through the spheres of the hostile planet-angels and rulers of the cosmos, and its return to its divine home in the "fullness" of God's light, a return which, to the gnostic's mind, signified Redemption. Some scholars consider this to be the central idea of Gnosticism. Certainly the description of this journey, of which a particularly impressive account is found in the second part of the "Greater Hekhalot", is in all its details of a character which must be called gnostic. ${ }^{16}$

\footnotetext{
12 "The outstanding documents of the movement appear to have been edited in the fifth and sixth centuries when its spirit was still alive and vigorous.", - cf. Scholem 1961, 44.

${ }^{13}$ Scholem 1965, 8.

14 "Palestine was the cradle of the movement, that much is certain.", - cf. Scholem 1961, 41.

${ }^{15}$ Scholem 1961, 47. Det forekommer mig, at forfatteren med ordspillet "secret knowledge" - "Gnosis" slipper temmelig let om ved problemstillingen.

${ }^{16}$ Scholem 1961, 49.
} 
Med bogen Jewish Gnosticism, Merkabah Mysticism, and Talmudic Tradition lader Scholem titlen tale sit tydelige sprog, og han fastholder hér, at der eksisterer en klar affinitet mellem Merkavahmystik og gnosticisme. Det havde andre, f.eks. Gaster, ganske vist også gjort før Scholem, men det var først med sidstnævnte, at dette tema blev uddybet. Han skriver således, at

If what these texts present is Gnosticism - and their essentially Gnostic character cannot in my opinion be disputed - it is truly rabbinic Gnosis, and the illuminations and revelations granted to the adepts are such as conform to the Jewish vision of the hierarchy of beings. Indeed, all these texts go to great lengths to stress their conformity, even in the most minute detail, to halakhic Judaism and its prescriptions. ${ }^{17}$

Sammenholder vi dette citat med det, som jeg bragte tidligere, må man konstatere, at Scholem fremsætter nogle temmelig uklare påstande. For det første hævdes det, at "The texts of Merkabah mysticism" udviser "an orthodox Jewish tendency", og at de på ingen måde kan siges at være kætterske; for det andet påståes det, således som vi lige har set, at disse tekster er gnostiske (sic!) - de tilhører oven i købet en kategori, som forfatteren kalder "truly rabbinic Gnosis" og passer til mindste detalje til "halakhic Judaism and its prescriptions." Der er med andre ord grund til at sætte et spørgsmålstegn ved Scholems opfattelse af "gnosticisme", idet han tilsyneladende opererede med et noget ejendommeligt gnosticismebegreb. Han skriver således, at

Only a few of the several sects, groups, and tendencies now considered "Gnostic" were known as such in their own time. But this does not preclude the use of this convenient term for the religious movement that proclaimed a mystical esotericism for the elect based on illumination and the acquisition of a higher knowledge of things heavenly and divine. ${ }^{18}$

Et andet sted søger Scholem så at fremhæve nogle karakteristika ved Merkavahmystikken ved at betone nogle træk i gnosticismen, som - ifølge forfatteren - er fælles for de to konceptioner:

So wenig in den uns erhaltenen Texten gnostische Mythen oder abstrakte Spekulationen über die Äonen und ihre Verhältnisse zueinander vorgetragen werden, so treffen doch auf die Mystik der Merkaba-Schriften fundamentale Charakteristika der Gnosis zu: der Besitz einer Erkenntnis, die nicht durch gewöhnliche intellektuelle Mittel, sondern nur auf dem Wege einer Offenbarung und mystischen Erleuchtung zu gewinnen ist, der Besitz einer Geheimlehre über die Ordnung der himmlischen Welten und die Kenntnis der liturgischen und theurgischen-magischen Mittel, die den Zutritt eröffnen. ${ }^{19}$

Det fremgår således af ovenstående, at Scholem anså gnosticismen for at være en mystisk esoterisme for nogle få udvalgte, som via en åbenbaring eller mystisk illumination samt kendskab til magiske midler kom i besiddelse af en hemmelig viden om den kosmologiske

\footnotetext{
${ }^{17}$ Scholem 1965, 10.

${ }^{18}$ Scholem 1965, 1.

${ }^{19}$ Scholem 1962, 18.
} 


\section{Øyvind Jørgensen}

orden. Dette er imidlertid en karakteristik, der ikke har vundet særlig stor tilslutning i forskerkredse. Mange mener således, at der hersker markante kosmologiske og soteriologiske forskelle mellem gnosticismen og Merkavahmystikken, hvilket dog ikke må få os til at lukke øjnene for de ligheder, der eksisterer mellem dem. Såvel i gnosticismen som i Merkavahmystikken opererer man med en "culture hero" eller budbringer, som - for gnosticismens vedkommende - bibringer mennesket den essentielle viden (gr. $\gamma v \tilde{\omega} \sigma \mathrm{c} \zeta$ ), og som - i Merkavahmystikken - i skikkelse af Moses, Rabbi Yishma'el eller Rabbi 'Aqiba videregiver adepten den afgørende viden om de magiske midler - hyppigt et eller flere gudsnavne - med henblik på den senere instrumentale udnyttelse. Magi spiller også en rolle i visse dele af gnosticismen, således som vi eksempelvis kender det fra Origines' Contra Celsum og det gnostiske skrift Pauli Apokalypse. Nogle forskere har da også fokuseret på dette aspekt i deres søgen efter fælles karakteristika. Alexander hævder således, at der er gode grunde til at antage, at magi har fungeret som en mediator mellem gnosticismen og Merkavahmystikken. ${ }^{20}$ Det er imidlertid uhyre vanskeligt at sige noget sikkert om karakteren af en eventuel gensidig - eller ensidig - påvirkning, idet det ville fordre, at Merkavahmystikkens geografiske og kronologiske udgangspunkt kunne bestemmes med større præcision, hvilket som bekendt (indtil videre) ikke har været muligt. Sammenfattende vil jeg konkludere, at det ikke er uproblematisk at fastholde tesen om en så snæver forbindelse mellem gnosticisme og Merkavahmystik, som Scholem tilsyneladende antog, selv om meget taler for et sådant synspunkt. ${ }^{21}$ For Scholem var der ikke tvivl om, at det centrale tema i Merkavahmystikken var synet af Guds himmelske trone, der indtræder som kulminationen på himmelrejsen, hvor mystikeren "stiger op" (i visse passager hedder det imidlertid, at han "stiger ned") gennem de himmelske sfærer eller paladser. Han skriver således:

What was the central theme of these oldest of mystical doctrines within the framework of Judaism? No doubts are possible on this point: the earlist Jewish mysticism is throne-mysticism. Its essence is not absorbed contemplation of God's true nature, but perception of His appearance on the throne, as described by Ezekiel, and cognition of the mysteries of the celestial throneworld. ${ }^{22}$

\footnotetext{
${ }^{20}$ Alexander 1984, 8 f.

${ }^{21}$ For en god ordens skyld skal det tilføjes, at der ifølge Scholem ikke blot var tale om en ensidig påvirkning fra gnosticismen til jødedommen, in casu Merkavahmystikken. Om de såkaldte Shiur Qomah-traditioner med deres spekulationer over den legemlige udstrækning af Gud, og som han med "monoteismen" som parameter (naturligvis) anså for at befinde sig inden for ortodoksiens rammer, var han tilbøjelig til at mene, at der gik en linie til den senere dualistiske gnosticisme i 2. årh. e.v.t. Han skriver således: "Angesichts des hohen Alters dieser Ideen, das wir tentativ bis ins 1. Jahrhundert zurückverfolgen konnten, erhebt sich auch die Frage, ob diese orthodoxe Schi'ur Koma-Gnosis nicht der dualistischen Aufspaltung der späteren Gnosis des frühen 2. Jahrhunderts voranging, und wir so eine ganz andere Entwicklungslinie der Gnosis vom Monotheismus zum Dualismus wahrnehmen können, als die uns bisher angeboten wird.", - cf. Scholem 1977, 27. Scholems til tider upræcise sprogbrug viser sig også hér - hvad menes der f.eks. med uđtrykket "orthodoxe Schi "ur Koma-Gnosis"?

${ }^{22}$ Scholem 1961, 43-44.
} 
Inden vi går videre, kan der være grund til at kaste et blik på den særlige anvendelse af verber til at beskrive himmelrejsen.

\section{Ekskurs: עלה = at stige op, eller = at stige ned}

Spørgsmålet omkring valget af verbum til beskrivelse af Merkavahmystikerens rejse har voldt mange problemer for eftertiden. Scholem mente eksempelvis, at der 0. 500 skete en ændring, dvs. fra עלה (stige op) til (stige ned), således som vi kan iagttage det i HR:

In the early literature, the writers always speak of an "ascent to the Merkabah," (...) The "Lesser Hekhalot" emphasize this "ascent", and the same term recurs in a few out-of-the-way passages of the "Greater Hekhalot," and in the introduction to the "Book of Enoch". But for reasons which have become obscure, the whole terminology had in the meantime undergone a change - it is difficult to say exactly when, probably around 500. In the "Greater Hekhalot," (...) and from then on in almost all the later writings, the visionary journey of the soul to heaven is always reffered to as the "descent to the Merkabah". The paradoxical character of this term is all the more remarkable because the detailed description of the mystical process nonetheless consistently employs the metaphor of ascent and not of descent. ${ }^{23}$

Senere fors $\varnothing$ ger Scholem at give en mere uddybende forklaring på fænomenet og påviser flere steder udenfor Hekhalotlitteraturen, hvorledes ירד har vundet indpas på bekostning af עלה Han mener således, at brugen af førstnævnte skal relateres til den talmudiske frase: יורד לפני התבה , dvs. at gå ned til arken/skabet (sc. med Torahrullen for at bede), idet opbevaringsstedet sammenlignes med Guds trone. ${ }^{24}$ Ithamar Gruenwald tilslutter sig denne forklaring:

We believe that the term "Yored Merkavah" does indeed derive from the term "Yored Lifne HaTeivah", and this for the simple reason that according to Hekhalot Rabbati, the person who is called "Yored LaMerkavah" is a kind of public emissary or more precisely: a medium entering into a mystical trance, describing to his fellow mystics that which he sees in heaven. ${ }^{25}$

Der er dog på dette punkt langt fra tale om nogen egentlig konsensus, og bl.a. Halperin giver et andet bud på problemets løsning. Med udgangspunkt i Ex 14 plæderer han for, at יר i Hekhalotlitteraturen skulle være afledt af brugen af dette verbum i Midrash Rabbah nærmere bestemt i ExRabbah 23,15 - i beskrivelsen af israelitternes nedgang til/overgang over Det røde Hav, - cf. Halperin 1988, 226-227. Denne for den religiøse og etniske selvforståelse overordentlige vigtige fortælling har ifølge Halperin dannet et paradigme, der kunne tjene som reference for Merkavahmystikernes himmelrejse. Andre forskere, eksempelvis Ira Chernus, har ment, at der kunne være tale om en "eufemistisk" anvendelse, således at ירד faktisk skulle betegne det modsatte, sc. עלה, - cf. Chernus 1987, 5.

Joseph Dan har fremhævet Højsangen som inspiration for Hekhalotlitteraturen med

\footnotetext{
${ }^{23}$ Scholem 1961, 46-47.

${ }^{24}$ Scholem 1965, 20.

${ }^{25}$ Gruenwald 1988, 171.
} 


\section{Øyvind Jørgensen}

henvisning til 6,11: “... אל-גנת אגות ירדת (Til valnфddehaven gik jeg ned ...), - cf. Dan, 34. Endelig bør det nævnes, at Annelies Kuyt med udgangspunkt i en fundamental uenighed med Scholem, således som hans synspunkt er kommet til udtryk i det ovenstående, har fremsat den hypotese, at oprindeligt har 'עלה smarere end anvendt som betegnelse for en rejse til Guds trone. Det vil imidlertid føre for vidt at komme nærmere ind på hendes argumentation i denne sammenhæng, - cf. Kuyt 1990, 45-69.

Som den sidste i rækken af mulige forklaringer på problemet vil jeg fremhæve den, som Bloch i slutningen af 1800-tallet fremsatte. Han tager ganske enkelt udgangspunkt i den stilling, hvori mystikeren kunne tænkes at have placeret sig med henblik på at opnå den mystiske oplevelse, hvilket - parentetisk bemærket - naturligvis forudsætter, at der har fundet en sådan oplevelse sted. ${ }^{26}$ Med inddragelse af et responsum fra Hai Gaon (d. 1038), hævder Bloch, at idet

... die Merkabah-Mystiker sich kopfüber die Kniee herabbeugten und das Gesicht zur Erde neigten, mussten sie nicht das Gefühl bekommen, als wenn sie mit ihrem Körper gleichsam in die Tiefe hinabgleiten und zur Merkabah hinabsinken? Aber selbst wenn ein solches Gefühl empirisch nicht nachweisbar wäre, so genügt das Herabsinken des Oberkörpers, wobei die Entkräftung infolge tagelanger Enthaltsamkeit von Speise und Trank wohl meistentheils den Verzückten zu Boden fallen liess, um schon wegen der körperlichen Haltung die Bezeichnung dieses Aktes als ein "Hinabsteigen zur Merkabah" zur rechtfertigen. ${ }^{27}$

Vi forlod Scholem i det foregående, men lad os vende tilbage og se, hvorledes han mente, at også andre emner udgjorde en væsentlig del af indholdet $i$ teksterne, som f.eks. brugen af magi under de til tider farlige rejser.

Scholem antog, at der eksisterede tre "udviklingstrin" eller stadier i Merkavahmystikken: et stadium, der var kendetegnet ved mystiske oplevelser, hvor magi spillede en forholdsvis lille rolle ${ }^{28} \rightarrow$ et stadium, hvor magi spillede en større samt mere aktiv rolle og var en integreret del af mystikken, således som vi kan iagttage det $i$ store dele af Hekhalotlitteraturen ${ }^{29} \rightarrow$ et stadium, hvor anvendelsen af magi ikke længere var tilstrækkelig

\footnotetext{
${ }^{26}$ Med hensyn til spørgsmålet om det er plausibelt at antage en eller anden form for "ritualiseret transliminal praksis", dvs. en mystisk oplevelse for Merkavahmystikeren, vil jeg henvise til min artikel i Nordisk Judaistik, Vol. 17, 1996, 140ff.

${ }^{27} \mathrm{Cf}$. Bloch, 25.

28 "At first the magical protection of a single seal may be sufficient, ...", - cf. Scholem 1961, 50. Således også Gruenwald 1980, 143. At tilstedeværelsen af magi/besværgelser i Hekhalotlitteraturen tilsyneladende har voldt Scholem vanskeligheder, kommer indirekte til udtryk med følgende udtalelse, hvor han hævder, at de magiske elementer: "... so far of being later additions or signs of spiritual decadence - a prejudice dear to the modern mind - belong to the very core of their particular religious system.", - cf. Scholem 1961, 51. Spørgsmålet er imidlertid, hvor han vil placere "the very core" - i det første eller det andet stadium?
}

29 "A brief and simple formula is no longer enough. Sunk in his ecstatic trance, the mystic at the same time experiences a sense of frustation which he tries to overcome by using longer and harder struggle to pass the closed entrance gates which block his progress. As his psychical energy wanes the magical strain grows and the conjuring gesture becomes progressively more strained, until in the end whole pages are filled with an apparently 
til at eliminere de forhindringer, der viste sig for Merkavahmystikeren på dennes vej. Dette sidste - stadium betegner if $\not$ lge Scholem afslutningen på Merkavahmystikken som en levende bevægelse, dvs. som en gruppe af aktivt udøvende mystikere, idet den "degenererede" til litterære produkter uden nogen egentlig forbindelse til samtidige mystiske oplevelser:

Every secret name seemed to provide a further piece of protective armour against the demons - up to the point where the magical energy was no longer sufficient to overcome the obstacles which blocked the way to the Merkabah. This point is really the end of the movement as a living force: from then on it degenerates into mere literature.

Sammenholder man Scholems synspunkter vedrørende tilstedeværelsen af magi i Merkavahmystikken, således som de kommer til udtryk i Major Trends in Jewish Mysticism og Jewish Gnosticism, Merkabah Mysticism, and Talmudic Tradition, må vi konkludere, at han på den ene side kontrasterede himmelrejserne med de magiske besværgelser, og på den anden side - da han indså betydningen af sidstnævnte - søgte at henføre magien til det senere stadium i Merkavahmystikken. Det er ligeledes evident, at han efterhånden så sig nødsaget til at acceptere, at himmelrejserne ofte optræder i forbindelse med en magisk besværgelse, hvilket især kommer til udtryk i $H Z$ - den tekst som han tillige anså for at indeholde de ældste traditioner i Hekhalotlitteraturen. Det er næppe forkert at drage den konklusion, at Scholems syn på de magiske elementer i Merkavahmystikken må siges at være negativt. Magi gøres til den faktor, der får Merkavahmystikken til at "degenerere" - de magiske elementer opfattes som "krykker", der tages i anvendelse af Merkavahmystikeren, når "his psychical energy wanes". Man fristes således til at hævde, at der ifølge Scholem eksisterer en slags omvendt proportionalitet mellem "mystik" og "magi" - jo mindre af førstnævnte desto mere af sidstnævnte. Eller - sagt på anden vis - jo mere "autentisk" eller "genuin" mystik vi har med at gøre, desto mindre rolle spiller den "degenerende" og "negative" magi. Jeg mener imidlertid ikke, at forholdet mellem "mystik" og "magi" $i$ denne sammenhæng er et "enten-eller". Der er intet i vejen for, at himmelrejsemystikken og de magiske besværgelser i Hekhalotlitteraturen kan anskues som teologisk (og kronologisk) sideordnede.

\section{Tiden efter Scholem - nyere positioner}

I de senere år har især Gruenwald, Halperin, Schiffman samt Schäfer beskæftiget sig intensivt med Merkavahmystikken, og i det følgende agter jeg at opholde mig ved disse. Der kunne naturligvis nævnes andre forskere, som har underkastet Merkavahmystikken en mere eller mindre dybtgående analyse, men jeg finder, at ovennævnte udgør et repræsentativt udsnit.

Gruenwald har bl.a. fokuseret på den jødiske apokalyptik som en slags referenceramme for Merkavahmystikken. I modsætning til Scholem hævder han således, at enhver tale om "Jewish Gnosticism" må forstumme, da de indbyrdes forskelle er for store til, at man med

meaningless recital of magical key-words with which he tries to unlock the closed door.", - cf. Scholem, 1961, 50. 


\section{Øyvind Jørgensen}

rimelighed kan tale om en egentlig "jødisk gnosticisme". ${ }^{30}$ Med hensyn til dateringen af traditionsstoffet $i H Z$ er Gruenwald dog enig med Scholem i dennes vurdering, og vil således tidsfæste teksten til 2. eller 3. årh. e.v.t. ${ }^{31}$

Som sagt fremhæver Gruenwald den jødiske apokalyptiks betydning for Merkavahmystikken, og det er da også plausibelt at antage, at særlig himmelrejsefænomenet har rødder tilbage til apokalyptikken. Men når det hævdes, at det på visse områder er forsvarligt at antage, at "Apocalypticism sprang out of the animosity certain circles in postbiblical times felt against the Jerusalem priesthood.", så er Gruenwald ude på fantasiens overdrev. Jeg mener ikke, at hans argumentation hviler på et forsvarligt grundlag. Termen "animosity" kan jo dække over flere ting, og vi ved faktisk ikke noget om, hvorvidt en sådan "Gefühl" har været til stede som en "resentment" rettet mod det jerusalemitiske præsteskab på denne tid i så høj grad, at den dannede grobund for himmelrejsespekulationerne. I denne forbindelse kan der være grund til at nævne, at der findes plausible argumenter for at antage, at den jødiske apokalyptik har rødder i prasstelige kredse kort før vor tidsregnings begyndelse. ${ }^{32}$

Andre forskere har i tidens løb beskæftiget sig med forholdet mellem Hekhalotlitteraturen og de ortodokse, rabbinske tekster. Halperin mener således i sin formkritiske studie, The Merkabah in Rabbinic Literature at kunne konkludere, at

The Palestinian rabbinic sources do not provide evidence for the existence of a mystical praxis, linked to the "Chariot" of the Book of Ezekiel, whose practitioners claimed that, in ecstatic trance, they explored supernatural realms and viewed celestial realities. Among rabbinic sources, only BT offers positive evidence that the rabbis believed in some sort of ecstatic mysticism which may have been connected with Ezekiel's merkabah. ${ }^{33}$

Senere skriver Halperin dog, at selv de babyloniske kilder, der synes at forbinde מרכבה med himmelrejser, opfatter ikke disse som en samtidig realitet - der er snarere tale om reinterpretationer af ældre kilder fra Palæstina. På dette punkt er han dog varsom, idet han i det følgende påpeger, at

It would not, of course, follow from this that non-rabbinic Jewish groups did not seek ecstatic

${ }^{30}$ Gruenwald 1988, IV-V, samt mere udførligt 191-205.

31 "Hekhalot Zutreti (or: Zutarti) is in all likelihood the oldest Hekhalot text proper that we possess. It is a collection of several short Merkavah-passages, some of which are in Aramaic. Professor Jonas Greenfield, who undertook a linguistic study of the Hebrew and Aramaic sections of the book, inclines to locate it in EretzYisrael, most probably in the second or third century C.E. This conclusion concurs with that of Professor Gershom Scholem, who on the basis of an analysis of its contents regards the book as representing the Merkavah lore of the Tannaitic, possibly early Amoraic, period.", - cf. Gruenwald 1980, 142. Det har desværre ikke været muligt at fremskaffe Greenfields utvivlsomt særdeles interessante studie - forfatteren nåede ikke at publicere unders $\varnothing$ gelsen før sin $\mathrm{d} \varnothing \mathrm{d}$.

${ }^{32}$ Cf. Benedikt Otzen, 136-142 samt 184-186.

${ }^{33}$ Halperin 1980, 179. 
experiences or claim to have attained them. We could not even exclude the possibility that certain rabbis secretly cultivated ecstatic techniques, without this being reflected in the rabbinic literature. ${ }^{34}$

Muligheden for at "certain rabbis" skulle have praktiseret "ecstatic techniques", anser jeg for at være realistisk, og jeg kan således ikke se, at der skulle have været noget til hinder for, at visse personer tilhørende en inderkreds af rabbinere skulle have været interesseret $i$ at prøve disse "ecstatic techniques" af i praksis.

I The Faces of the Chariot uddyber Halperin sine synspunkter vedrørende forfatterproblematikken i Hekhalotlitteraturen samt - sidst men ikke mindst rekrutteringsgrundlaget i Merkavahmystikken, og hævder således, at det bagvedliggende motiv var en klassekamp med udgangspunkt i עם הארץ rettet mod en privilegeret gruppe, sc. rabbinerne ${ }^{35}$. Han hævder således, at

The authors of the Hekhalot did more than borrow the ascension theme from the synagogue tradition. They made it into a paradigm of their own struggle with the rabbinic elite for a place of honor within Jewish society - an unequal and frustrating struggle which they waged with magic as their chief weapon. (...)

For the ascension myth is inherently and essentially revolutionary. It is very nearly a mirror image of the ancient myth of Lucifer, the rebellious deity who tries to set his throne above the stars and is therefore hurled down to hell. More exactly, it is the Lucifer myth told from the rebel's point of view, with the rebel victorious. Both, I suspect, are rooted in the psychological reality of the younger generation challenging the old. The difference lies in the sympathies of the narrator. ${ }^{36}$

Halperins syn kan umiddelbart virke forfriskende og inciterende, men jeg er ikke sikker på, at han har ret i sine påstande. Jeg mener, at der findes lige så stærke indicier, der peger i den modsatte retning: kravene om såvel besiddelse af et højt kundskabsniveau (ikke blot mht. det traditionelle jødiske lovstudium, men også vedrørende metoposkopi og astrologi) som en vis værdighed hos Merkavahmystikerne/adepterne fremgår således af flere passager i

\footnotetext{
${ }^{34}$ Halperin 1980, 184.

35 "They are the "am ha' ares, litterally "people of the land". These appear in rabbinic sources as folk without the rabbis' expertise in Torah, refinement of manners, or scrupulousness of ritual observance; Jews whom the rabbis often despised and loathed, and who often responded by hating the rabbis." - cf. Halperin 1988, 437-438. At der somme tider har eksisteret et antagonistisk forhold mellem 'am ha'ares og rabbinerne, forekommer mig at være ganske plausibelt, og Halperin underbygger da også dette med citater fra bl.a. bT.
}

${ }^{36}$ Halperin 1988, 450-451. Andre forskere har været inde på lignende tanker i deres undersøgelser af gnosticismens opkomst og rekrutteringsgrundlag, dvs. at en utilfredshed med sociale, økonomiske, kulturelle og/eller politiske forhold kom - symbolsk - til udtryk i gnosticismen. Cf. Hans Kippenberg, 211-231; Kurt Rudolph, 35l-44, samt - i større omfang - Henry Green i The Economic and Social Origins of Gnosticism fra 1985. Ingen af disse nævnes imidlertid hos Halperin på trods af, at man må formode, at deres teser må have været gefundenes Fressen for ham. Scholem fremsætter - noget uklart - også tanken om, at et ydre pres, in casu oldkirkens, kunne tænkes at have "directed the religious interests of the mystics towards the higher world of the Merkabah;" - cf. Scholem 1961, 73. 


\section{Øyvind Jørgensen}

Hekhalotlitteraturen. ${ }^{37}$ Det må ej heller glemmes, at vi i den talmudiske litteratur finder en polemik rettet mod visse rabbinere, som anså det for muligt at lytte til en guddommelig stemme, בת קול, mhp. en ellers uopnåelig afgørelse af forskellige halakhiske stridspunkter herfra er springet til Merkavahmystikernes anvendelse af magi $i$ - fristes man til at sige kundskabens tjeneste ikke særlig langt. ${ }^{38}$ Jeg mener således ikke, at der eksisterer overbevisende grunde til at antage, at Merkavahmystikerne en bloc skulle have udgjort en særlig gruppe af outcasts, som følte sig henviste til skyggesiden "within Jewish society". Spørgsmålet om rekrutteringsgrundlaget er imidlertid ganske kompliceret, idet vi præsenteres for forskellige svar i de forskellige tekster. I $H Z$ er sigtet således meget elitært det er hovedsagelig kun de to culture heroes, sc. Moses og R. 'Aqiba, som nyder himmelrejsens privilegium og derpå videregiver den magiske viden til en udvalgt gruppe, som så kan forsøge at gøre dem kunsten efter, og det hele er omgærdet af et krav om hemmeligholdelse, der understreger det esoteriske præg ved forløbet. I andre dele af Hekhalotlitteraturen, eksempelvis i makroformen Merkavah Rabbah, sporer man en tilbøjelighed til at "demokratisere" Merkavahmystikken, og i sådanne tilfælde kan man altså tale om en eksoterisk tendens. ${ }^{39}$ Sammenfattende mener jeg dog, at store dele af Hekhalotlitteraturen afspejler mere eller mindre eksplicitte krav til Merkavahmystikkens participanter af en sådan karakter, at det ville være ganske forkert at tale om et åbent, bredt og folkeligt fænomen eller bevægelse, endsige at der skulle være tale om "the younger generation challenging the old".

\section{Qumran og Merkavahmystikken}

Forholdet mellem Qumran og Merkávahmystikken er bl.a. blevet berørt af Schiffman. I artiklen Merkavah Speculation at Qumran: The $4 Q$ Serekh Shirot 'Olat ha-Shabbat konkluderer han, at vi blandt teksterne finder materiale, der mht. sprog, terminologi og stil minder meget om visse passager i den senere Hekhalotlitteratur..$^{40}$ Der er ifølge Schiffman dog grund til at mane til en vis forsigtighed:

The material studied here reflects some significant differences from later hekhalot literature. We have a description of the goings on in heaven. There is no ascent or guided tour. The sect simply describes what can be known from its vantage point. This information comes primarily from an exegesis of the merkabah visions of Ezekiel and related biblical texts. Therefore, there is no incubation or preparation for a mystical "journey".

\footnotetext{
${ }^{37}$ Schäfer har offentliggjort et manuskript, nærmere bestemt G 12, om metoposkopi og astrologi, - cf. Schäfer, $1984,135-139$.

${ }^{38}$ Cf. Efraim E. Urbach, 300-302.

${ }^{39}$ Mht. termerne mikroform og makroform vil jeg henvise til min artikel i Nordisk Judaistik, Vol. 17, No. 1-2, 1996, 139, note 2.

${ }^{40}$ Schiffman, 15-47.
} 
Det er evident, at man ideelt bør skelne mellem en spekulativ/eksegetisk beskæftigelse med teologiske og kosmologiske emner og en mystisk oplevelse centreret omkring de samme temaer. I praksis kan det imidlertid ofte være vanskeligt at gennemføre denne distinktion, idet teksten ikke altid giver et entydigt svar på dette.

På trods af de signifikante forskelle mener Schiffman imidlertid, at Qumran har været en potentiel kilde til Merkavahmystikken:

..., it is possible to conclude that merkavah mysticism had its origin at Qumran or in related sectarian circles. From there it somehow penetrated and was absorbed by Pharisaic and then tannaitic tradition. It would be through these channels that this speculation entered into the mainstream of Judaism. ${ }^{41}$

Hvad der helt præcist menes med, at Merkavahmystikken "entered into the mainstream of Judaism" uddyber Schiffman desværre ikke, men jeg vil sætte et spørgsmålstegn ved denne formulering. Hvis der med udtrykket sigtes til, at Merkavahmystikernes gudsbegreb var det traditionelle jødiske, dvs. at de - en masse - var ortodokse, må jeg opponere imod dette. Men hvis Schiffman tænker i sociale kategorier, dvs. at nogle af disse mystikere udadtil tilhørte såkaldte "inner circles" eller rabbinske kredse og - fysisk, så at sige - ikke skilte sig ud fra majoriteten, således som gruppen bag Dødehavsteksterne eksempelvis gjorde det, er jeg mere positiv indstillet.

\section{Pseudepigrafi og Merkavahmystik}

Som tidligere omtalt eksisterer der ikke en egentlig fastlagt kánon for Hekhalotlitteraturen, og forskellige udgaver eller redaktioner af teksterne har yderligere bidraget til at vanskeliggøre arbejdet med denne litteratur. Efter at have arbejdet med at redigere store dele af materialet udgav Schäfer imidlertid en Synopse zur Hekhalotliteratur, der var systematiseret på en klar og overskuelig måde. ${ }^{42}$ Men dermed være ingenlunde sagt, at vejen nu ligger åben for en let og problemfri tilgang til materialet, hvad det tekstkritiske aspekt angår - Schäfers Synopse opererer ikke med en Urtext i den forstand, at vi bliver præsenteret for et enkelt originalt manuskript.

Schäfer vil datere Hekhalotlitteraturen til at være post-talmudisk, idet han hævder, at Merkavahmystikerens world-view er for fremmedartet til at kunne rummes i de kredse, der stod bag Mishnah, Talmud og Midrash. Et andet argument for denne kronologiske bestemmelse er - stadigvæk ifølge Schäfer - at de talrige passager i Hekhalotlitteraturen, der indledes med "Rabbi Yishma'el sagde: '..." eller "Rabbi “Aqiba sagde: '...", hvilket naturligvis har til hensigt at autorisere og legitimere det konkrete budskab eller indhold, skulle indicere, at teksterne må anses for at være pseudepigrafisk litteratur, der er nedskrevet

\footnotetext{
${ }^{41}$ Schiffman, 46 .

${ }^{42}$ Mht. yderligere kildeangivelser hos Schäfer vil jeg henvise til min artikel i Nordisk Judaistik, Vol. 17, No. 1-2, 1996, 139, note 1 .
} 


\section{Øyvind Jørgensen}

efter talmudisk tid, hvor "censuren" næppe har været så effektiv som tidligere. ${ }^{43}$ Disse iagttagelser kan - indrømmet - vanskeligt negliceres, men jeg mener ikke, at det sidste ord dermed er sagt. Det kunne tænkes, at just den pseudepigrafe karakter skulle tilskrives det forhold, at visse dele, omend ikke samtlige teksters indhold, hidrørte fra talmudisk tid - ja, man kunne måske gå et skridt videre og antage, at der kunne være tale om personer $\mathrm{i}$ de rabbinske cirkler, som i det skjulte plejede omgang med mere eller mindre excentriske individer, hvorfra Merkavahmystikken udsprang. Halperin tangerer - som tidligere omtalt jo også denne tanke, selv om han har svært ved at acceptere, at det skulle forholde sig således. Jeg mener, at vi må antage dette som en mulighed, der er ligeså plausibel som Schäfers tese.

\section{Afsluttende forskningshistoriske betragtninger}

Hvad der ovenfor er blevet sagt om tidligere tiders af og til indifferente holdning til jødisk mystik, må til en vis grad også siges at gøre sig gældende, når man kaster et blik på den forskningshistoriske reception af magi i den senantikke jødedom. Først omkring midten af 1800-tallet kan man iagttage en for øget interesse for magi, men vel at mærke som en del af folkloristikken, således som det bl.a. kom til udtryk i et fag som "jüdische Volkskunde". 44 Dette må vække nogen undren i dag, idet magi vel kan anskues som en faktor i det spirituelle - og dermed religionshistorisk set interessante - meningssystem, der dannede grundlag for store dele af den nærorientalske kultur i tiden før såvel som efter vor tidsregnings begyndelse. En del af den ligegyldighed (og til tider intense polemik), der har været rettet mod det magiske aspekt af jødedommen - og for den sags skyld også kristendommen - som et forskningsobjekt, har utvivlsomt lange rødder. At magi i en eller anden udtryksform ikke desto mindre har eksisteret enten sideløbende $\mathrm{i}$ et ofte antagonistisk forhold til den institutionaliserede religion, eller som en mere eller mindre integreret del af denne, er evident, og eksemplerne er legio. ${ }^{45}$

\footnotetext{
43 "The Hekhalot literature is thus not a literature of the rabbis, yet it seeks to stand in continuity with the Rabbinic literature. For this reason it appears quite improbable to me that the goals and ideals propagated in this literature were developed at the same time as those of Rabbinic Judaism in the form of Misnah, Talmud and Midrash. In other words: The completely pseudepigraphical character of the Hekhalot literature is an important argument for the assertion that this literature is in fact a post-Rabbinic phenomenon." - cf. Schäfer 1988, 293. Som det fremgår af ovenstående, deler jeg på nuværende tidspunkt ikke dette synspunkt.
}

${ }^{44}$ Gideon Brecher var således blandt de første, som offentliggjorde en studie af magi i jødisk kontekst, - cf. G. Brecher, Das Transcendentale, Magie, und magische Heilarten im Talmud, 1850.

${ }^{45}$ Magi møder vi eksempelvis i Ex 22,18; Lev 19,26; Deut 18,9-10; 1 Sam 28,3; Matt 8,28-34; Mark 1,25f; Joh 2,11; Acta 5,15-16. Visse dele af Jesu virksomhed udviser en klar forbindelse med magi, således som også Morton Smith i Jesus the Magician fra 1978 har påvist. M. J. Geller har i sin artikel, "Jesus' Theurgic Powers: Parallels in the Talmud and Incantation Bowls", vist, at Jesu "djævleuddrivelser", således som disse er overleveret i NT, har visse paralleller i Talmud (både den babyloniske og den palæstinensiske) samt i aramæiske besværgelsesskåle fra Nippur. Han konkluderer, at "It is, however, the Jesus exorcisms which are common to all three sources, since each describes incantations inwoking Jesus' name, which demonstrates that exorcisms of the 
Med Ludwig Blau's værk, Das altjüdische Zauberwesen, fra slutningen af 1890'erne, kom der lidt mere fart over feltet. Opdagelsen af de græske magiske papyri og deriblandt tekster med umiskendelige jødiske elementer, har utvivlsomt været en impuls for Blau til at kaste sig over dette emne. Han antog, at kilderne til de jødiske magiske traditioner hovedsagelig var at finde i de strømninger, der var udgået fra henholdsvis Ægypten og Babylonien, - et synspunkt der i øvrigt findes formuleret $\mathrm{i}$ Talmud. ${ }^{46}$

På trods af bogens indiskutable kvaliteter må man konstatere, at forfatteren ikke formåede at opretholde en tilstrækkelig distance til sit objekt - hans egen forståelse af magi var i for høj grad determineret af kildernes kvantitative begrænsning af dette tema. Senere fulgte andre forskere i kølvandet på Blau, og i dén forbindelse bør Joshua Trachtenberg nævnes, som med Jewish Magic and Superstition fra 1939 hovedsagelig fokuserede på magiens folkloristiske aspekt - undertitlen var "A Study in Folk Religion" - i den francogermanske jødedom i middelalderen.

I de senere år har tidligere tiders forskellige fund af amuletter, besværgelsesskåle etc. ført til en forøgelse af mængden af litteratur om disse emner, og der kan således være grund til at gøre status over kildesituationen.

Ifølge Alexander kan man opdele kilderne til den tidlige jødiske magi i to kategorier: 1) de tekster, der hidrører fra Tanakh, den intertestamentale litteratur (dvs. apokryfer, pseudepigrafer, Josephus), Det nye Testamente, de tidligste traditioner i Talmud og Midrash, og endelig andre ikke-kristne samt kristne tekster. Som kronologiske fixpunkter er disse overleveringer naturligvis meget vigtige, men de udgør et noget snævert grundlag for en dybtgående undersøgelse af jødisk magi. En sådan må tillige baseres på 2) de kilder, der eksplicit beskriver de magiske ritualer og det magiske univers, og hér står forskningen kronologisk set hyppigt på bar bund, hvilket naturligvis ikke er ensbetydende med, at den videnskabelige diskurs må forstumme. Den sidstnævnte kategori af kilder kan stort set opdeles i to grupper, sc. a) tekster, der i en narrativ form giver læseren et større indblik i magiens karakter og betydning for dens udøvere; $;^{47}$ og b) tekster - ofte formler, men også længere tekststykker - fra "incantations/magical bowls" eller besværgelsesskåle, samt forskellige amuletter etc. Disse "magical bowls", der blev opdaget i slutningen af 1880'erne, er som sagt beskrevet med forskellige magiske besværgelser og navne etc. på aramæisk samt - i mindre grad - på mandæisk og syrisk, og stammer, både mht. materiale og indhold fra Babylonien (is. Nippur) i årene 300-600 e.v.t. I Palæstina og Syrien har man på nogenlunde samtidige amuletter af metal eller andet materiale ligeledes fundet talrige vidnesbyrd om magiens udbredelse i såvel præ- som posttalmudisk tid. En stor del af disse tekststykker skildrer såkaldte almindelige menneskers forskellige behov og $\emptyset$ nsker, - f.eks. beskyttelse mod sygdomme, beskyttelse af ejendom, afværgelse af ulykker etc., og vidner således om magiens folkelige udstrækning i datidens jødiske population. I både den antikke og den hellenistiske/senhellenistiske samt jødiske kultur gives der talrige eksempler på, hvorledes man har gjort brug af magi til visse mere eller mindre konkrete formål, og medtager man

N.T., Talmud, and magic bowls form a single genre of magical literature." - cf. M. J. Geller, op. cit., 155.

${ }^{46}$ Cf. bT Qiddushim 49,b

${ }^{47}$ Hér tænkes på tekster som f.eks. ספר הרזים og. Hekhalotlitteraturen tilhører ligeledes denne gruppe a). 


\section{Øyvind Jørgensen}

hele kildematerialet, så rækker spektret fra besværgelser til Gud vedrørende ønsker om "usynlighed", magiske formler for et mere attraktivt udseende, behandling af opsvulmede testikler samt opretholdelse af erektion, - for blot at nævne nogle af de mere kuriøse tilfælde. ${ }^{48}$ Dette må dog ikke få os til at tro, at anvendelsen af magi i Merkavahmystikken har haft en tilsvarende folkelig appel.

En ikke ubetydelig del af interessen for magi i jødisk kontekst har været rettet mod en anden kildegruppe, sc. gruppe b). John A. Montgomery offentliggjorde således i begyndelsen af dette århundrede en udgave af de aramæiske besværgelsestekster fra Nippur. ${ }^{49}$ Dette værk blev senere efterfulgt af nogle korrigerende udgivelser af andre forskere og i denne forbindelse bør Schiffman og Michael D. Swartz nævnes, idet de med Hebrew and Aramaic Incantation Texts from the Cairo Geniza fra 1992 har beskæftiget sig med besværgelsestekster i et udsnit af Geniza-amuletter og fundet nogle få specifikke paralleller mellem Hekhalotlitteraturen og de pågældende - der er således referencer til Guds trone og de engle, som bærer denne, i nogle af besværgelserne.$^{50}$ Englen Metatron og hans 70 navne optræder ligeledes som tema i én af amuletterne. Det er evident, at man skal være yderst varsom med at drage definitive konklusioner vedrørende eventuelle litterære afhængighedsforhold, hvilket forfatterne da også afholder sig fra.

Sluttelig kan det nævnes, at to publikationer, sc. Amulets and Magic Bowls: Aramaic Incantations of Late Antiquity fra 1985, og Magic Spells and Formulae: Aramaic Incantations of Late Antiquity fra 1993, begge forfattede af Joseph Naveh og Shaul Shaked, må siges at have påvist udbredelsen af palcestinensiske magiske traditioner i et omfang, som man hidtil ikke havde antaget. ${ }^{51}$

\section{Hekhalotlitteraturen i dens foreliggende form}

I det følgende er det min hensigt at undersøge nogle få passager i henholdsvis Hekhalot Zutarti og Ma'aseh Merkavah (MM), hvor et magisk element indgår som en illokutionær handling, der for Merkavahmystikeren har til formål at frembringe en anden og mere

\footnotetext{
${ }^{48}$ Cf. f.eks. Karl Preisendanz (Hrsg.), passim, samt Urbach, $129 f$.

49 J. A. Montgomery, Aramaic Incantation Texts from Nippur fra 1913.

${ }^{50}$ I to sådanne referencer anvendes ordet מרכבה imidlertid ikke som betegnelse for Guds trone, men derimod det mere "almindelige" כס.

51 "The amulets from Palestine (...) contain magical material which is as much part of a living tradition as the magical texts from Babylonia. One may go even further and say that a comparison of the metal amulets from Palestine and surrounding countries to the magic bowls from Mesopotamia shows in several cases clear Palestinian influences and only rarely if ever can one detect influences in the other direction.", - cf. J. Naveh \& S. Shaked 1993, 21.
} 
attraktiv tilstand eller egenskab. ${ }^{52}$ Hensigten er således ikke at undersøge samtlige passager i Hekhalotlitteraturen, hvor der forekommer magi, men derimod kun et repræsentativt udsnit af de passager, der forekommer mig relevante for mit tema.

Forinden vil jeg dog knytte et par bemærkninger til Hekhalotlitteraturen i dens foreliggende form.

Det er ganske tydeligt, at flere passager i de manuskripter, der udgør Merkavahmystikkens litterære materiale, består af forskellige "selvstændige" enheder, hvilket atter nødvendiggør et vist detektivarbejde, for at man kan danne sig et større overblik. Det er vigtigt at understrege, at der med udtrykket "selvstændige" sigtes til den redaktionelle medfart, som teksterne har været udsat for i tidens løb - hovedsagelig foretaget af Haside Ashkenaz. I denne forbindelse finder jeg det værd at citere Halperin, når han om Hekhalotlitteraturen, således som denne er systematiseret hos Schäfer, skriver:

Open Schäfer's Synopse at any point - it usually does not much matter where you start a Hekhalot text - and you find yourself plunged into a swirl of hymns, incantations, divine names, and fantastic descriptions of heavenly beings. All of this usually seems to be assembled in no discernable pattern and to no discernable purpose..$^{53}$

Dette skal ikke opfattes som en negativ kritik af Schäfers arbejde, hvilket kommer indirekte til udtryk hos denne selv, når han i Hekhalot-Studien giver udtryk for, at

Die Hekhalot-Literatur ist nicht mehr eindimensional in einem genetisch-linearen und damit statischen Modell zu beschreiben, sondern kann nur noch durch ein mehrdimensionales und damit dynamisches Modell adäquat erfaßt werden. ${ }^{54}$

Schäfers karakteristik er dog en anelse kryptisk, og jeg mener, at udtrykket "mehrdimensionales und damit dynamisches Modell" slet og ret bør opfattes som en eufemisme for det faktum, at teksterne ofte synes at være kompilerede "in no discernable pattern and to no discernable purpose". Jeg kan ikke se, at dette skulle være behæftet med noget positivt, således som Schäfer med sit ordvalg giver udtryk for.

Det er evident, at et udgivelsesarbejde af den karakter, der hér er tale om, har været

\footnotetext{
${ }^{52}$ Hekhalot Rabbati $(H R)$ indeholder langt færre besværgelser end $H Z$. I $H R$ møder vi flere steder passager, sc. de såkaldte gedullah-hymner, der røber en eskatologi, der i højere grad minder om de tanker, som vi finder i Qumran end i den traditionelle, talmudiske jødedom. Det er således interessant at konstatere, hvorledes forskellige perikoper i $H R$ fokuserer på Merkavahmystikerens alvidenhed, idet denne - sammen med den magiske potens - er med til at markere vedkommendes stilling i forhold til Gud og dermed den særlige teologi i Merkavahmystikken.

Gruenwald har antydet, at det er værd at overveje, om Merkavahmystikken ab initio kan betragtes som en slags antieskatologisk reaktion, idet folk ikke længere var interesserede $i$, hvad der eventuelt ville ske med dem i én eller anden mere eller mindre fjern fremtid, men ønskede hic et nunc at opleve "the celestial bliss". Han konkluderer, at "... on the whole merkava mysticism has nothing specifically important to say in matters of eschatology, and may, therefore, be taken as quite neutral from the eschatological point of view." - cf. Gruenwald, 1973, 106. Set ud fra et ekskatologisk synspunkt er det dog tvivlsomt, om Merkavahmystikken kan siges at være "neutral", hvad der så end sigtes til med dette udtryk.

${ }^{53}$ Halperin 1988, 367.

${ }^{54}$ Schäfer 1988, 3.
} 


\section{$\emptyset y v i n d$ J $\phi r g e n s e n$}

forbundet med talrige vanskeligheder. Man må gøre sig klart, at Synopse zur HekhalotLiteratur ikke indeholder "festumrissene und endredigierte Schriften, die zur 'Gattung' Hekhalot-Literatur zählen, sondern Handschriften." ${ }^{55}$ Med fremhævelsen af at der er tale om "Handschriften" sigter Schäfer til, at disse har været udsat for en større grad af "manipulation" eller redaktion, end tilfældet formodentlig ville have været, dersom der havde været tale om egentlige "bøger" eller "festumrissene und endredigierte Schriften". Men denne skæbne deler de som bekendt med mange andre litterære produkter fra såvel antikken som middelalderen.

Jeg vil således tillade mig at konkludere, at vi har med nogle skrifter at gøre, der vel bedst kan karakteriseres som værende "fluktuerende" i henséende til kompilationen af det traditionsmateriale, der danner basis for dem. Mht. en nærmere bestemmelse af traditionernes fulde omfang er vi faktisk - i hvert fald for $H Z$ 's vedkommende - lidt i vildrede, idet vi hverken er $\mathrm{i}$ besiddelse af en introduktion endsige en egentlig afslutning. ${ }^{56}$

\section{Hekhalot Zutarti}

Jeg vil indlede min undersøgelse med Hekhalot Zutarti, idet denne tekst kan siges at være den mindst homogene af de nærværende tekster og - sidst men ikke mindst - omfatter adskillige passager med magiske elementer, der er relevante for mit forehavende. ${ }^{57} \mathrm{HZ}$ anses af nogle forskere (Scholem o.a.) for at indeholde de ældste traditioner i Hekhalotlitteraturen, hvilket dog må siges at være et stærkt omdiskuteret synspunkt. Der er - som sagt ingenlunde tale om en redaktionel helhed - snarere tværtimod. Scholem bemærkede, at således som $H Z$ er overleveret ("preserved"), er der tale om "something of a hodgepodge", hvilket altså rummer en kerne af sandhed. 58

Det er ikke min hensigt at foretage en opdeling af $H Z$ eller de $\emptyset$ vrige tekstkorpus efter et bestemt mønster. I det følgende vil jeg fremdrage nogle perikoper, således som disse

${ }^{55} \mathrm{Cf}$. Schäfer 1981, V. For en mere detailleret gennemgang af de forskellige problemer $\mathrm{i}$ forbindelse med udgivelsen af Hekhalotteksterne samt yderligere oplysninger om de enkelte manuskripter vil jeg henvise til Schäfer, op. cit., V-X.

${ }^{56}$ I $\$$ 427, M 22 finder vi dog en "afslutning", idet der står: נשלם ספר מעשה מרכבה. Man bør dog være opmærksom på, at מעשה מרכבה ofte anvendes som et appellativ for forskellige tekster, - cf. Schäfer 1988, 220.

${ }^{57}$ Idet jeg følger Schäfers afgrænsning, vil jeg lade Hekhalot Zutarti strække sig over $\$ \S 335-426,-$ cf. Schäfer 1988, 51-54. I et responsum fra Hai Gaon omtales der to tekster, sc. היכלות רבתי ("Det store værk om de Himmelske Paladser") og היכלות זוטרת ("Det lille værk om de Himmelske Paladser"). Dette er så vidt vides det ældste "datérbare" belæg for tekster med disse navne, - cf. Halperin 1980, 3. Hai Gaons omtale må ifølge Halperin sigte til $H Z$, $\$ 424$, - cf. Halperin 1988, 374.

${ }^{58}$ Scholem 1965, 83. Schäfer udtaler sig kategorisk om dette problem, når han hævder, at $H Z$ “erweist sich somit als das Musterbeispiel einer Textfiktion, deren redaktionelle Einheit wahrscheinlich niemals bestanden hat. Spekulationen über das Alter der HZ im Vergleich zu anderen Texten der Hekhalot-Literatur sind völlig fehl am Platze. Wenn überhaupt, kann nur über das Alter einzelner Textstücke diskutiert werden, nicht aber über das Alter einer redaktionellen Einheit Hekhalot Zutarti.”, - cf. Schäfer 1988, 62. 
fremstår i Synopse. Der vil mao. være tale om lectio selecta.

$H Z$ indledes med en beskrivelse af, hvorledes en person skal iagttage nogle forholdsregler, dersom vedkommende $\varnothing$ nsker at få mulighed for at opleve "verdens hemmelighed" og "visdommens skjulte ting". ${ }^{59}$ Når jeg på trods af tekstens umiddelbare mangel på magiske elementer alligevel har valgt at medtage ovenstående "indledning" til $H Z$, så skyldes det for det første, at vi hér gøres bekendte med den eksklusive del af Merkavahmystikken; for det andet pointeres det, at mystikerens forehavende er forbundet med en vis fare: vedkommende skal indprente sig denne mishna og være forsigtig med den indtil sin dødsdag. Lidt længere fremme i teksten hedder det, at han skal være værdig ליופיות המרכבה, dvs. "til Merkavah'ens skønhed", og stykket afsluttes med en formaning til mystikeren om at holde tand for tunge. ${ }^{60}$ Disse ting kan tilsammen siges at være et indicium på Merkavahmystikkens overvejende esoteriske karakter. Faremomentet samt de magiske elementers psykologiske virkning på mystikeren, eller den arketypiske "helt" R. Yishma 'el, kommer også til udtryk i en passage fra ét af Genizä-fragmenterne, sc. G 8, hvor det hedder, at

Og når du kommer til det sjette palads, så er der skarer af prinsèr og prinsers prinser samt troppers prinser og tropper og atter tropper, fordi indgangen til det andet palads skubbes frem og flyder med samt frembinger store mængder og lejre og hjælpere på én gang. Og der er ingen forhindring, men du bliver ikke skadet, thi du holder (שת = er grebet af) et stort tegn/segl, og alle det Højes engle frygter det ... ${ }^{61}$

Hér fortælles det således, at R. Yishma 'el vil forblive uskadt ved sin ankomst til det sjette palads (היכל שישי) på trods af tilstedeværelsen af "talrige skarer af prinser og tropper", idet han er i besiddelse af et stort tegn/segl (חותם גדול). Dette tegn/segl er tilsyneladende af apotropæisk karakter, idet skal beskytte ham mod disse horder af fjendtligsindede væsener. Det er dog ikke altid tilstrækkeligt at anvende et tegn/segl. Vi har i et andet Genizafragment, G 22, vidnesbyrd om, hvorledes R. Yishma'el tillige får overrakt en seglring (טבעת) til brug for himmelrejsen. Ordet "seglring" forekommer flere steder i Hekhalotlitteraturen.

I den næste perikope, som jeg har valgt, sc. § 336, fortælles der om Moses' opstigning til Gud - et tema vi jo genkender fra Ex 19,3 samt 20 og igen i 24,12-18, dvs. overdragelsen af Torah'en til Moses. Denne rolle som "culture hero" møder vi altså også i Hekhalotlitteraturen. I nærværende tekststykke er der tale om en konkret viden, der

59

$\S 335, \mathrm{O} 1531$

38 אש אתה רוצה להתיחד בעולם לגלות לך רזי 39 עולם וסתרי חכמה (שו\{הוי שומה את המש:ה 40 השאת והוי זהיר בה

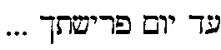

60

$\S 335, \mathrm{O} 1531$

45 כבור אלהים הסתר דבר כדי שלא 46 תטרד מן העולם ...

61

G8, $2 \mathrm{a}$

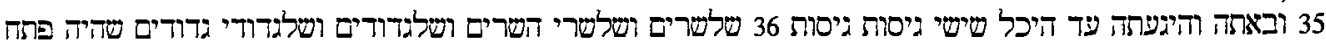

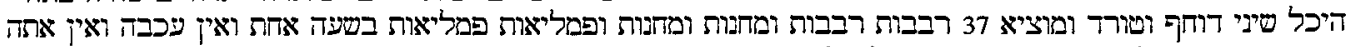

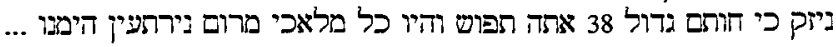


overdrages til Moses, nærmere bestemt 9 navne, og de sætter senere Merkavahmystikeren i stand til at lære Torah uden at løfte en finger, så at sige. Det er evident, at der i tidens løb er givet flere bud på etymologien bag disse nomina magica, og vi genfinder da også nogle af dem i en græsk eller koptisk udgave i andre sammenhænge. Det vil således næppe være forkert at konkludere, at de 9 navne eller nomina magica, hvoraf et par som sagt har vist sig at være græciserede semitismer og - nærmere bestemt - gudsnavne, tjener magiske formål i den besværgelse, der skal tilsikre Merkavahmystikeren at lære og ihukomme hele den jødiske tradition med hjertet. Det er mao. ikke tilstrækkeligt, at der eksisterer et sådant ønske hos mystikeren, idet denne vil glemme "alt det, som jeg forstår/hører og lærer" ('כל מה שאני (שומע ולומד (שר), dersom der ikke tages magiske midler i brug. Der er imidlertid ikke tale om, at den som udfører den magiske handling, in casu udtalelsen af nomina magica, selv foretager en himmelrejse. Merkavahmystikeren forsøger altså at "skyde genvej" til at erhverve sig kundskab om hele det jødiske traditionsgods, sc. Torah, hvilket naturligvis giver anledning til at spørge, om dette er foreneligt med den traditionelle forestilling om Torah'ens rette overlevering til menneskene? Eller man kunne også med Schäfer spørge, om der er ikke tale om et brud med (eller en nytolkning, om man vil) den traditionelle historieforståelse, når Merkavahmystikeren således søger at ophæve tiden mellem åbenbaringen på Sinai og den messianske endetid? Hvad implicerer dette mht. Merkavahmystikkens teologi? Jeg finder det tillige bemærkelsesværdigt, at messiaskonceptionen så at sige ikke spiller nogen rolle i Merkavahmystikken - kunne det tænkes, at dette fravær skyldes en forestilling om, at Merkavahmystikeren får del i den messianske funktionalitet vha. de magiske midler? Det er imidlertid ikke min hensigt at besvare disse spørgsmål i denne artikel, idet det fordrer en større og mere dybtgående unders $\varnothing$ gelse af hele Hekhalotlitteraturen, men jeg mener nok, at det er værd at overveje disse spørgsmål på nuværende tidspunkt.

I en anden perikope, sc. $§ 337$, hører vi om en potentielt farlig viden i form af et "navn", der er overdraget en anden "culture hero", sc. R. "Aqiba under hans skuen af Merkavah'ens struktur (מעשה מרכבה). I modsætning til det foregående får vi hér ikke noget at vide om, hvad det er for et navn, der er tale om. Det fremgår eksplicit, at der er tale om en videreformidling af "navnet" til R. Aqiba's "elever" (תלמידיו), og dette efterfølges af en advarsel til disse om dets styrke og kraft: hvis der ikke udvises den rette forsigtighed, så ... konsekvenserne udmales ganske vist ikke, men det er nærliggende at antage, at de vil være ganske alvorlige. ${ }^{62}$

Sammenligner man nu det foregående tekststykke ( $\$ 336$ ) med ovenstående, er det evident, at der må være tale om to traditioner med hver sin "hovedperson", og kaster vi et blik på ét af Geniza-fragmenterne, sc. G 7, viser det sig, at teksten i § 336 ikke forekommer dér. Slutningen af $\S 335$ glider så at sige direkte over i $\S 337$, og eftersom G 7 indeholder det (hidtil) ældste manuskript med dette tekststykke, er det nærliggende at betragte $§ 336$

62

2 זוזו השם שנגלה לר' עיקיבא שהיה מסתכל 3 במעשה מרכבה וירד עקיב'ולימד אותו 4 לתלמידיו אמ'להם בגיי הזהרו

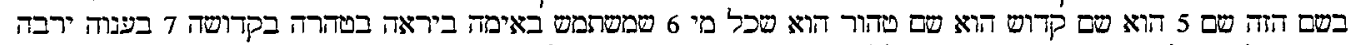
זרע ויצלח בכל דרכיו ויאריכו 8 ימיו בא' יוי אשר קדשנו במצותיו. על קדושת 9 השם ... 
som en senere interpolation i $H Z^{63}$

Det er nærliggende at drage den konklusion, at der med "navnet" $i$ det foregående sigtes til ét af Guds talrige navne, hvilket da også synes at blive bekræftet af en lovprisning i slutningen af tekststykket (ב'א' יוי אשר קדשטו במצותיו על קדושת השם). Inden jeg går videre med tekstanalyserne, vil det imidlertid være på sin plads, at kaste et nærmere blik på gudsnavnene i Merkavahmystikken.

\section{Ekskurs: Onomatologi og teologi i Merkavamystikken}

Det er tydeligt for enhver, som har beskæftiget sig med Hekhalotlitteraturen, at der hyppigt kommer en bestemt onomatologi til udtryk. I teksterne finder vi allehånde navne, der i den konkrete kontekst næppe forekommer læseren meningsfulde. Vi har således i ovenstående tekstudsnit set, hvorledes forskellige nomina barbara sammen med andre - mere eller mindre letgennemskuelige - navne overbringes en "culture hero" for dernæst at videregives til den potentielle adept. Flere steder i Hekhalotlitteraturen făr man endda det indtryk, at det er nok så meget de enkelte bogstaver, der er "grundelementet", som de navne, der dannes af dem. Det hedder eksempelvis om Merkavahmystikeren, at "Han nævner bogstaver, så at han ikke tager skade: 'zyyp php zrs'",64

I 3 Enok møder vi en forestilling, der synes at bekræfte bogstavernes magiske betydning, idet vi et sted i teksten, hvor "himmelguiden", dvs. den $\emptyset$ verste engel, Metatron, afslører visse kosmologiske sammenhænge for R. Yishma 'el, læser følgende passus: "R. Yishma'el sagde: Metatron sagde til mig: 'Kom og jeg vil vise dig bogstaver(ne), med hvilke himle og jord blev skabt ..." og bakker" etc. Om samme figur, Metatron, hedder det, at han har 70 navne, der hver især betegner en eller anden funktion, dvs. at der er tale om en onomatologisk magtkoncentration. Vi ser en tilsvarende opfattelse bag anvendelsen af nomina barbara/magica, og sekvensen af bogstaver/tegn er tillige bestemt ud fra det konkrete formål, hvilket atter implicerer, at en given ændring - metatese, om man vil - af et navn kan få ubehagelige følger for mystikeren, idet der skabes en ny og måske farlig magtkoncentration.

Der er visse ting, der tyder på, at de guddommelige navne har været sunget eller er indgået i én eller anden rytmisk kontekst. Karl-Erich Grözinger har påvist en sammenhæng mellem hymner og visioner, og det er plausibelt at antage, at indholdet af disse hymner (eller nogle af dem) har været gudsnavne, nomina divina. Denne formodning bestyrkes af flere loci i Hekhalotlitteraturen. I $H R$ hedder det således, at

${ }^{63}$ Hvilket synes at stemme overens med A. Kuyts hypotese om, at verbet עלד של udtryk for en senere udvikling. Det bør i sagens natur tilføjes, at G 7 ikke indeholder $\$ \S 335$ og 337 verbatim et litteratim, men der er dog tale om, at langt størstedelen af materialet er gengivet i manuskriptet, der skal dateres til før midten af 11 . årh.

64

$\S 561$, O 1531

56 ויזכיר אותות שלא יתמוק. זייך פחק זריץ

65

32 אמר ר' שמעאל אמר מטטרון לי בא ואראך אותיות שיבראו בו שמים וארץ. 


\section{Øyvind $J_{\emptyset r g e n s e n}$}

R. Yishma'el sagde: "Alle disse hymner hørte R. Aqiba, da han steg ned til Merkavah. Og han tog dem og lærte dem foran hans herlighed, som hans tjenere sang foran ham." ${ }^{, 66}$

I Ma 'aseh Merkavah læser vi: “... en hymne er hans navn, og hans navn er en hymne ..."67

Med disse få eksempler mener jeg at kunne konkludere, at de guddommelige navne er af overordentlig stor betydning for Merkavahmystikeren qua nomina magica og magthypostaser. I $H Z$ siges det eksplicit, at gudsnavnet er udtryk for magt:

Dette er magtens navn. Lykkelig enhver, som kender det og udtaler det i renhed: hans Torah står i hans hånd. ${ }^{68}$

At den særlige onomatologi også spiller en rolle mht. åbenbaringen forekommer nærliggende. Israels udvælgelse blandt folkeslagene kan m.a.o. ses i lyset af Guds åbenbaring af sine navne til Merkavahmystikerne, således som det kommer til udtryk i en doksologi fra $H Z$ :

Og han sagde: "Priset være du, הח, vor Gud, verdens konge, som har helliggjort os med sine bud, og har adskilt os fra alle folkene og har åbenbaret os sine skjulte ting [eller: hemmeligheder], og som har beredt os for at lære/erkende sit store og frygtelige navn. ${ }^{69}$

Kilden til visdom siges flere steder at udspringe fra lovprisningen af nomina divina - et forhold der særligt tydeligt kommer frem i en perikope fra $M R$, hvor vi læser, at

Ved dit navns lovprisning bliver visdoms hemmelighed åbenbaret. Og i hymne til din tanke bliver hemmeligheders hemmeligheder og erkendelses porte åbnet ... ${ }^{70}$

Pudsigt nok er det hverken den mundtlige eller skriftlige Torah, der prises som reservoir for

66

$\S 106,01531$

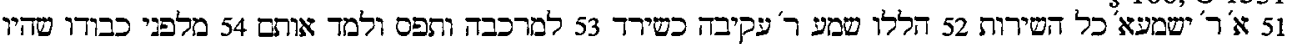
משוררין לפניו 55 משרתיו.

67

$\S 588,01531$

16 שיר שמו ושמו שיר ....

68

$\S 365, \mathrm{O} 1531$

19 זה הוא שם של גבורה אשרי כל יודעו ומזכירן 20 בטהרה תורתו מתקיימת בידו.

69

$\S 384, \mathrm{~N} 8128$

23 ואו' ברוך אהה ידוה אלהינו מליך העולם אשר 24 קרשנו במצותיו ודברילנו מכל האומות וגילה לנו את מסתריו

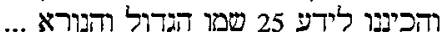

70

27 בשבח שמך סתר חכמה יתגלו. ובשירת זכרך סתרי סתרים 28 ושערי ביגה יפתחו ... 
visdom og erkendelse. Det er tillige interessant at bemærke, at vi er $\mathrm{i}$ besiddelse af doksologier, der kunne tyde på et identitetssammenfald mellem nomina divina og guddommen, idet de karakteriseres med samme attributter efter et mønster, der følger alfabetet. Det hedder således i $H Z$, at:

Du er vældig, og dit navn er vældigt. Du er modig, og dit navn er modigt. Du er velsignet, og dit navn er velsignet. Du er udvalgt, og dit navn er udvalgt. ... ${ }^{71}$

og fortsætter således i det følgende. Formodningen om, at der hersker et sådant identitetsforhold, bliver endnu tydeligere i $M M$, hvor vi læser følgende: "Han er sit navn,

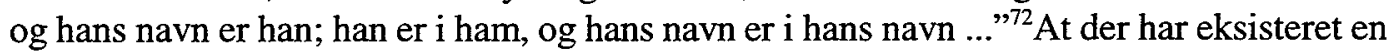
vis forbindelse mellem gudsnavnet og dets ejer, kan næppe forekomme overraskende - vi ved jo, at det ikke var tilladt at udtale tetragrammet undtagen i den aronitiske velsignelse og i ypperstepræstens bønner på Yom Kippur, og Urbach har argumenteret for, at forbudet mod denne udtale var iværksat med det formål at "... prevent the blurring of the distance between God and man and the use of the Name for magical purposes."73

Sammenfattende kan det konkluderes, at der med Merkavahmystikkens teo- og onomatologi er taget skridt i retning mod en nytolkning, der indgår som et nødvendigt led i den magiske konception, der ligger til grund for mystikerens tilværelsesforståelse.

Vender vi nu tilbage til Hekhalot Zutarti, møder vi i de følgende strofer de efterhånden velkendte culture heroes, Moses og R. 'Aqiba. Om førstnævnte hører vi, at da han steg op til Gud, fortalte denne ham, hvorledes "ethvert vildfaret menneske" (כל אדם שלבו שוגה עליו) kan bringes på "ret køl":

Nævn til ham disse navne:איום יהוה צבאות אה בהז יה ביה יהואל יהואל. I, hellige navne! Åbn, åbn mit hjerte. Alt hvad jeg forstår [eller: hører], hvad enten det er Torah'ens ord eller hele verdens ting/forhold, så skal de bevares i mit hjerte, og det skal i al evighed ikke glemmes af mig. ${ }^{74}$

Ved første øjekast forekommer ovenstående at være en slavisk gentagelse af $\S 336$, som vi tidligere har berørt, idet "hovedpersonen", sc. Moses, optræder med samme funktion og i samme kontekst i de to tekststykker. Men der gør sig dog også visse forskelle gældende: for det første er der tale om andre navne med en magisk funktion; for det andet rækker magiens virkningsgrad længere i nærværende tekst, end hvad vi så i § 336. Der er således ikke blot

71

$\S 391, \mathrm{~N} 8128$

48 אתה אדיר ושמך אדיר. אתה אמיץ ושמך 49 אמיץ. את'ברוך ושמך ברוך. את'בחור ושמך בחור.

72

$\S 588, \mathrm{O} 1531$

15 דוא שמו ושפו הוא הוא בהוא ושמו 16 בשמו ...

${ }^{73}$ Urbach, 124-134.

74

$\S 340, \mathrm{~N} 8128$

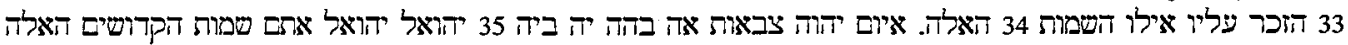

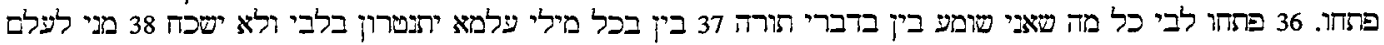




\section{$\emptyset$ yvind Jørgensen}

tale om, at Torah'ens ord skal bevares i menneskets hjerte, men også שמות הקדושים, de magiske navne - hér kaldet "hellige navne", idet de forlener vedkommende med en alviden, hvilket atter kan siges at afspejle et $\emptyset$ nske hos Merkavahmystikeren om at kunne beherske eller betvinge hele verden.

Spørgsmålet om tilstedeværelsen af en "manual" eller "bog", har naturligvis optaget forskningen, og i nedenstående tekst forekommer der da også en passage, der kunne tyde på noget sådant:

Dette er bogen tilhørende visdommen og indsigten og erkendelsen og udforskningen af det $\varnothing v r e$ og det nedre, Torahs yderste og himlene og jorden og de skulte ting, som blev givet til Moses, søn af Amram, af erkendelsen vedrørende יה יה אחהיה יאו צבאות Israels Gud, og Han åbenbarede [sc. bogen] for ham på Horeb, ... ${ }^{75}$

Der er tilsyneladende tale om en "bog" (לחות, dvs. tavler), der er blevet overdraget Moses på Horeb. Vi har muligvis hér et vidnesbyrd om en "manual"(jf. ovenstående), med hvilken Moses udførte diverse former for magi, således som vi kender til disse fortællinger fra Tanakh. Gruenwald hævder at "we may assume that the book which is meant is none but Hekhalot Zutreti itself”, hvilket må siges at bero på en fejlagtig opfattelse af, hvad der egentlig gemmer sig bag Hekhalot Zutreti/Zutarti. ${ }^{76}$ Som Schäfer tidligere har gjort opmærksom på er det ikke korrekt at anvende termen "bog" om $H Z$. Det eneste vi i denne sammenhæng kan tale om, er en "makroform" af $H Z$. Dette bringer os imidlertid ikke nærmere en egentlig løsning på problemet vedrørende identifikationen af ספר $\pi$, dvs. denne bog.

En anden - og i mine øjne plausibel - konklusion kunne være, at vi hér står med et udsagn om, at der senest med den sidste redaktion (sandsynligvis før denne) er sket en skriftlig fiksering af den mystiske praksis, og dette har Merkavahmystikerne så anvendt til en mere "struktureret" form for mystik. Tavshedsaspektet i Merkvahmystikken understreges jo meget hyppigt, og det har alt andet lige utvivlsomt været betragteligt lettere for mystikerne at (ud)danne og kontrollere en esoterisk praksis som denne, dersom man har haft en normativ "bog" eller "manual" til rådighed. Det ville dog være forkert at hævde, at indførelsen af en skriftlig form skulle være ensbetydende med, at Merkavahmystikken qua transliminal praksis (jf. note 2) hermed "degenerede" til en blot bevidstløs recitation af gudsnavne. Vi ved faktisk ikke noget som helst om dette, og jeg føler mig ingenlunde overbevist om, at det skulle forholde sig således. Man må ej heller se bort fra den mulighed, at en skriftlig fiksering kunne tænkes at forøge ordenes legitimation og autoritet.

Et stykke længere fremme i $H Z$ fremhæves den soteriologiske betydning af at kende til de magiske gudsnavne. Det hedder eksempelvis, efter en længere (rytmisk?) opremsning, i $\S 376$, at

75

41 זה ספר חכמה וביבה ודעת ומהקורי מעלה 42 ומטה צפוני ותורה ושמים. וארץץ וסתרים שנתן 43 ואל משה בן עמרם.

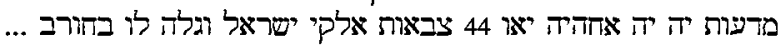

${ }^{76}$ Gruenwald 1980, 145. 
De sagde: "Enhver, som kender denne hemmelighed, for ham er det sikkert, at han tilhører den kommende verden. Han bliver reddet fra Gehenna's dom og fra alle hårde dekreter og fra al slags straf. Han bliver reddet fra al slags trolddom, idet han redder os og lader os undslippe og befrier os ... 77

Det sigses ganske tydeligt i dette stykke, at kendskabet til de tidligere fremførte nomina divina, hér antydet med ordene "denne hemmelighed", sc. ikke eksplicit, men må formodes at forholde sig således - udsigelsen af disse, har soteriologisk betydning for Merkavahmystikeren. Selve indledningen "De sagde ..." refererer naturligvis til den gruppe af "culture heroes", som vi tidligere har stiftet bekendtskab med. Vi kan altså konstatere, at gudsnavnene så at sige garanterer mystikeren del i den kommende verden - vedkommende optræder i kraft af sit kendskab til ii iר som en "religious expert", som er fri for Guds dom, hårde dekret og straf. Dette kunne atter indicere en nytolkning af den traditionelle historieforståelse, således som denne kommer til udtryk i den ortodokse talmudiske jødedom. Der kan næppe herske tvivl om, at det er vigtigt for Merkavahmystikeren (som for enhver anden) at undslippe Guds dom.

Som et sidste eksempel på forekomsten af magi i $H Z$ vil jeg fremdrage nedenstående perikope, hvor det tydeligt siges, at Gud har åbenbaret sig for R. 'Aqiba og vil opfylde dennes ønsker etc.:

Den store, mægtige og frygtelige, den overlegne og stærke Gud, som er tildækket for alle skabningers øjne og skjult for Tjenesteenglene, men synlig for R. 'Aqiba i Ma'aseh Merkavah for at kunne opfylde hans ønsker/mål. Det er det, der står skrevet: "Enhver, som er kaldet i mit navn. Således opfylder han min vilje, mit ønske og mit krav og enhver bøn fra mig. Amen, amen, amen. Selah.,"78

Forud for denne tekst er der udtalt en besværgelse, der bla. består af gudsnavne, således som vi i andre sammenhænge har iagttaget det. Man kan i denne sammenhæng tale om, at der ekisterer et perlokutioncert aspekt ved disse nomina divina, når de bliver udtalt af de såkaldte "religious experts", sc. Merkavahmystikerne. Det "demon language", som besværgelserne også består af, udgør det kommunikative element, som et religiøst ritual må indeholde, for at der kan skabes kontakt mellem mennesket og den guddommelige sfære eller "den anden verden". Når Gud (האל) i ovenstående tekst - og andre loci i Hekhalotlitteraturen - prises som værende "mægtig og frygtelig etc., er det helt i overensstemmelse med Merkavahmystikkens teo- og onomatologi, idet gudsnavnenes magiske virkekraft derved forøges.

Sammenfattende kan vi konkludere, at de magiske elementer i Hekhalot Zutarti, således

77

$\S 377, \mathrm{~N} 8128$

58 אמרו כל היודע רז זה מובטח לו שהוא בן העולם הבא. וניצול מרין גיהיט 59 ומיט ומכל גזירות קשות ומכל מיני פורענות

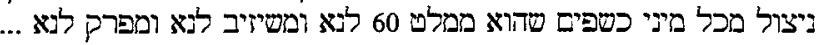

78

$\S 421,01531$

15 ... האל דגדול הגבור 16 ודנורא הכבירביר והחזק שהוא נעלם מעיני 17 כל כל הבריות ונסתר ממלאכי השרת וגנלה לו

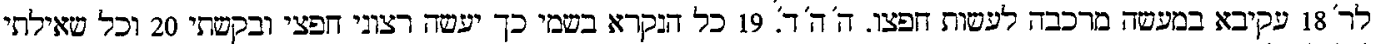

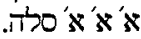




\section{Øyvind Jørgensen}

som de kommer til udtryk i de unders $\varnothing$ gte tekster, tydeligvis afslører en tilstedeværende instrumentalisering af gudsbegrebet i en sådan grad, at det er nærliggende at tale om en afvigelse fra den traditionelle jødiske teologi. Som jeg tidligere har pointeret, må dette dog ikke føre til, at vi dermed afviser den mulighed, at Merkavahmystikerne skulle befinde sig i det talmudiske milieu.

\section{- Ma'aseh Merkavah}

Som vi har set i det foregående, viser det sig også hér, at vi møder udsagn, der er lagt i munden på rabbinere fra 2. årh. e.v.t., sc. R. 'Aqiba og R. Yishma'el. Navnet "Ma'aseh Merkavah" må siges at være lidt af en tilsnigelse, idet det ikke findes i nogle af manuskripterne i forbindelse med nærværende makroform. Vi møder det i $\$ 427$ i en ganske anden kontekst, der hører til $H Z$, og at navnet har vundet indpas som "overskrift" må med Scholem forståes som en påvirkning fra et manuskript fra R. Eleazar af Worms, hvor denne omtaler en tekst som "Ma'aseh Merkavah". 79

Fortællerammen i $M M$ består stort set af beretninger eller udsagn fra R. 'Aqiba og R. Yishma 'el, samt gengivelser af samtaler mellem sidstnævnte og dennes lærer, R. Nehunya b. Haqanah. En ikke ubetydelig del af $M M$ er viet til bønner og besværgelser, og de magiske elementer har således en fremtrædende plads, således som de følgende tekstuddrag vil vise.

I nedenstående perikope ser vi, hvorledes R. 'Aqiba priser Merkavahmystikeren lykkelig, idet denne er i stand til at skue Guds trone/herlighedens trone:

R. "Aqiba sagde: "Lykkeligt er det menneske, som står i al sin kraft og bringer en lovsang for "ברוכ

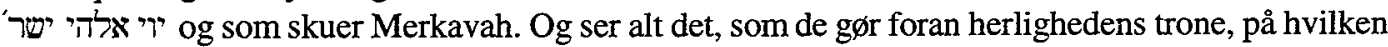
ברוכיי יוי אלהי ישר' sidder. Og han [sc. Merkavahmystikeren] ser til bud og til magt, love og til gode forordninger, så at han ophæver hårde forordninger fra verden, og han vil ikke udstøde sine fæller med (ב) שניטען פרוגג יוי אלהי ישר (ב), hvis navn er som hans magt, og hans magt er som hans navn. Han er sin kraft, og hans kraft er han, og hans navn er som hans navn [herefter: nomina divina/magica afsluttende med: "'אחד אה הה יהו" er hans navn"]

Antager vi, at subjektet for verbet בטל (dvs. adskille, afsondre, ophave) er den, som "skuer Merkavah", dvs. Merkavahmystikeren, så er denne tilsyneladende i stand til at gribe ind i verden og "ophæve hårde forordninger". Desuden kan han - i givet fald - udstøde sine fæller med nomina divina/magica. Det siges ganske vist ikke eksplicit, at disse forordninger

${ }^{79}$ Cf. Scholem 1965, 101-102.

80

$\S 557,01531$

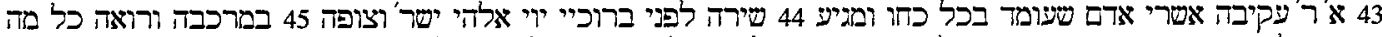

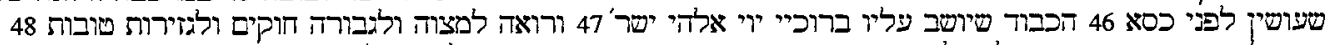

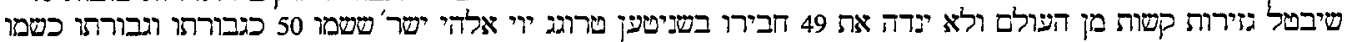

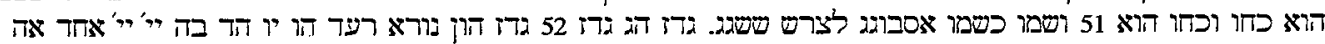


stammer fra Gud selv, eller fra menneskene (den romerske besættelsesmagt?) for den sags skyld, men jeg hælder til den anskuelse, at de hidrører fra førstnævnte. Hvis dette er korrekt, fristes man til at hævde, at Merkavahmystikeren hér optræder som en slags korrektiv til Gud.

I overensstemmelse med hvad vi tidligere har set i ekskursen om onomatologien i Merkavahmystikken, finder i ovenstående et eksplicit udtryk for, at Guds navn er hans magt et vice versa. Mystikeren kan mao. få del i denne potens ved at udnytte sit kendskab til gudsnavnenes iboende kraft. Besværgelsen af disse navne bevirker, at han "ser til bud og til magt, love og til gode forordninger, så at han ophæver hårde forordninger fra verden".

Når vi talrige steder i Hekhalotlitteraturen møder den ene lovprisning efter den anden af Gud, skyldes det, at den bagvedliggende tankegang opererer med en slags ligefrem proportionalitet mellem Guds almagt og hans navnes instrumentale potentiale. Merkavahmystikerens muligheder for at bruge nomina divina/magica i sin egen interesse, hviler mao. på den faste forestilling, at Gud er kilden til disse navne - ja, man kan endda hævde, at for Merkavahmystikeren gælder det, at Gud er sine navne. Dette forhold bekræftes også af en anden perikope, hvor vi efter al sandsynlighed har med en besværgelse at gøre, der ifølge traditionen er lagt i munden på R. Yishma ${ }^{\circ}$ el. Der indledes på vanlig vis med en bekræftelse af Guds potentat, hvorefter den besværgende udtaler nomina divina, i hvilke der

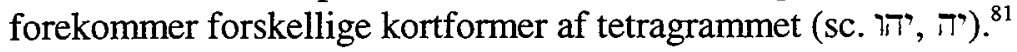

Som et sidste eksempel på gudsnavnemagien i $M M$ og den dermed forbundne afvigelse fra den traditionelle teologi, vil jeg fremdrage en tekst, hvor vi tydeligt kan iagttage sammenhængen mellem mystikerens doksologiske udsagn om Gud og understregningen af gudsnavnenes betydning som "magtkoncentrationer":

... Velsignet være du "[et Ms har: יהוה], ene Gud, skaber af sin verden med sit ene navn, udformer det hele med et ord. I himles høje har du grundlagt din trone ... ${ }^{82}$

Gudsnavnets skabende funktion kommer tydeligt frem i ovenstående, og det er just denne egenskab, som Merkavahmystikeren er i stand til at udnytte ved at lade dette og andre gudsnavne indgå i de magiske ritualer. Efter endeløse lovprisninger af Gud fokuserer teksten dernæst på "navnet", således som det kommer til udtryk i det følgende:

... og ingen er som dit store navn i evighed og evigheders evigheder. Det vredes på havet, og dette udtørrer; det stirrer på jorden, og den ryster. For din magt ryster hele verden. Det gør døde levende, og lader de døde opstå af deres støv. Dit navn er stort i evighed, vældigt er dit navn i evighed, helligt er dit navn i evighed. Gud er én ... [nomina divina]. Derfor påkalder vi dit navn, lovpriser din magt ... ${ }^{83}$

${ }^{81}$ Cf. $\S 562$, O $1531(1.3-15)$

82 $\S 596,01531$ 5 ב ב'א' י'אל אחד בורא 6 עולמו בשמו אחד יוצר הכל במאמר אחד 7 במרומי שמיש כונגת כסאך ...

83

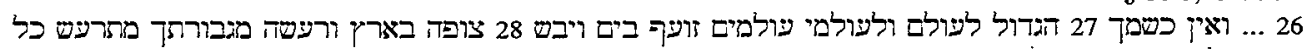

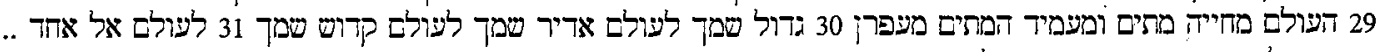

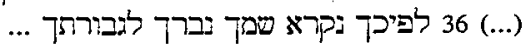


Gudsnavnet indeholder en "magt", der eksempelvis kommer til udtryk, når "det stirrer på jorden", så denne ryster, eller når det "gør døde levende", så de opstår. Det prises i toner, der, hvad indholdet angår, ligger helt på linie med de lovprisninger af Gud, som vi tidligere har set. Der kan næppe herske tvivl om, at for Merkavahmystikeren er nomina divina at regne for nomina magica, der kan indgå $\mathrm{i}$ et magisk ritual, dvs. som en illokutionær handling, der har til formål at opfylde forskellige ønsker eller tilvejebringe ændrede tilstande. I $M M$ optræder Merkavahmystikeren således med en bevidsthed om sin magiske kompetence der svarer til, hvad vi har set i $H Z$.

\section{Afsluttende konklusion}

Den foregående undersøgelse har vist, at vha. sit kendskab til gudsnavnene, således som disse er blevet videregivet af forskellige "culture heroes", er Merkavahmystikeren i stand til at få magt over de guddommelige sfærer i et sådant omfang, at han i visse tilfælde må siges at have distanceret sig i forhold til traditionens Gud, idet denne tjener som middel til opnålse af mystikerens egne ønsker. Med nomina divina/magica som "værktøj" for Merkavahmystikeren står Gud til disposition i et hidtil ukendt omfang. Dette forudsætter naturligvis, at der består en ganske snæver forbindelse mellem Gud og disse navne, hvilket ovenstående tekster da også synes at bekræfte. De talrige doksologier, der findes i de forskellige perikoper har til formål at forstærke gudsnavnenes magiske potentiale. Der eksisterer altså en slags ligefrem proportionalitet mellem lovprisningerne og nomina divina/magica.

Det er evident, at sproget spiller en stor rolle som det medium, gennem hvilket den mystiske erfaring formidles. Sprog har ikke blot et informativt aspekt - i Merkavahmystikken tillægges det tydeligvis også magt. Steven Katz hævder således, at

... I would like to consider this idea in several of its additional manifestations, beginning with the conception that language directly aids in mystical ascents to other worlds and realms of being.

In this context, words have locomotive power. They transport the spiritual self from the world below in the world above. Perhaps the clearest experience of such a doctrine, an unambigous representative expression of such compelling force, (...) is found in the Hekhalot and Merkavah texts of the rabbinic era ... ${ }^{84}$

Sproget er både dynamisk og profylaktisk, idet det på én gang - eventuelt kombineret med visse $\emptyset$ velser - baner vejen for bl.a. visionen af Merkavah og himmelrejsen, og beskytter mystikeren mod de lurende farer. Moshe Idel er inde på lignende overvejelser, når han skriver, at

This ancient Jewish body of literature [sc. Hekhalotlitteraturen] contributes the theory that the Torah, the divine names, and the alphabet in general are existing, apparantly even preexisting, in

${ }^{84} \mathrm{Katz}, 20-21$. 
the divine world as part of the divine retinue, sometimes even as inscribed on the divine body. (...) the view of the Hekhalot literature provides an important element to the magical understanding of the nature of the Hebrew language. ${ }^{85}$

Den magiske forståelse af sproget, in casu hebraisk/aramaisk, spiller mao. en vigtig rolle for Merkavahmystikerens world view. Guds åbenbaring, således som den er beskrevet på forskellig vis i litteraturen og bl.a. har givet sig udslag i Torah, er et udtryk for hans גבורה, dvs. hans magt. Urbach har formuleret dette synspunkt meget præcist, når han siger, at "The divine power finds expression in Revelation, in the Revelation of the Torah. ${ }^{, 86}$ Men dermed er det også indlysende, at det gudsbegreb eller den teologi, der er blevet blotlagt i nærværende undersøgelse, har distanceret sig fra det traditionelle gudsbillede. Dette må imidlertid ikke, således som jeg tidligere har gjort opmærksom på, få os til at drage definitive konklusioner vedrørende rekrutteringsgrundlaget for Merkavahmystikken. Der er, vil jeg fastholde, ikke noget til hinder for, at en del af "medlemmerne" af denne esoteriske bevægelse kom fra det talmudiske milieu. Jeg har tidligere berørt det faktum, at vi i Hekhalotlitteraturen finder eksempler på, hvorledes der forekommer eksplicitte krav til adepterne, hvilket gør det plausibelt at forestille sig, at vedkommende almindeligvis var en איש דברים, dvs. en lærd, som i disse konventikler kunne få tilfredsstillet sin interesse (nysgerrighed?) for magi, samtidig med at han kunne tilgodese sit behov for teologisk refleksion, desuagtet - eller måske fordi - dette overskred de rammer, der var fastlagt med den ortodokse tradition. Vi behøver mao. ikke at lede efter "ydre faktorer", således som Halperin har gjort (jf. ovenstående), når vi skal finde motiver eller bevæggrunde hos adepterne til at blive יורד המרכבה. Dermed være naturligvis ikke sagt, at sådanne ydre årsager ikke kunne tænkes at spille en rolle for enkelte individer, men jeg tror indtil videre ikke, at det har været et så grundfæstet træk ved rekrutteringen, som Halperin antager.

\section{Litteratur}

Alexander, Philip S., 1977, "The Historical Setting of the Hebrew Book of Enoch", i: Journal of Jewish Studies, Vol. 28, 173-180.

-, 1984, "Comparing Merkavah Mysticism and Gnosticism: An Essay in Method", i: Journal of Jewish Studies, Vol. 35, 1-18.

Bloch, Phillip, 1893, "Die ורדי מרכבה, die Mystiker der Gaonenzeit, und ihr Einfluss auf die Liturgie", i: Monatsschrift für Geschichte und Wissenschaft des Judenthums, 37, (New Series 1), $18-25 ; 69-74$.

Brecher, Gideon, 1850, Das Transcendentale, Magie, und magische Heilarten im Talmud, Wien.

Chernus, Ira, 1987, "The Pilgrimage to the Merkavah: An Interpretation of Early Jewish Mysticism",

i: J. Dan (ed.), Proceedings of the First International Conference on the History of Jewish Mysticism. Early Jewish Mysticism, Jerusalem.

Dan, Joseph, 1984, Three Types of Jewish Mysticism, Cincinnati.

Gaster, Moses, 1893, "Das Shiur Komah", i: Monatsschrift für Geschichte und Wissenschaft des Judenthums, 37, (New Series 1), 179-185; 213-230.

${ }^{85}$ Idel, 48.

${ }^{86}$ Urbach, 94. 


\section{$\emptyset$ yvind Jørgensen}

Geller, M. J., 1977, "Jesus' Theurgic Powers: Parallels in the Talmud and Incantation Bowls", i: Journal of Jewish Studies, Vol. 28, 141-155.

Goldberg, Arnold M., 1969, Untersuchungen über die vorstellung von der Schekhinah in der frühen rabbinischen Literatur, Berlin.

Graetz, Heinrich, 1859, "Die mystische Literatur in der gaonäischen Epoche", i: Monatsschrift für Geschichte und Wissenschaft des Judenthums, VIII, 67-78; 103-118; 140-152.

Green, Henry A., 1985, The Economic and Social Origins of Gnosticism, Atlanta.

Gruenwald, Ithamar, 1973, "Knowledge and Vision", i: Israel Oriental Studies, III, 63-107.

-, 1980, Apocalyptic and Merkavah Mysticism, Leiden-Köln.

-, 1988, From Apocalypticism to Gnosticism, Frankfurt a. Main.

Halperin, David J., 1980, The Merkabah in Rabbinic Literature, New Haven.

-, 1988, The Faces of the Chariot, Tübingen.

Hermann, Klaus, 1994, Massekhet Hekhalot. Traktat von den himmlischen Palästen, Tübingen.

Idel, Moshe, 1992, "The Reification of Language in Jewish Mysticism", i: S. Katz (ed.), Mysticism and Language, New York, 42-79.

Jørgensen, Øyvind, 1996a, "Magiens dæmonsprog - introduktion til S. J. Tambiah", i: Religionsvidenskabeligt Tidsskrift, Nr. 29, 55-75.

- , 1996b, "Om "mystik", Hekhalotlitterturen, og dens syn på forholdet mellem Gud og Metatron", i: Nordisk Judaistik, Vol. 17, No. 1-2, 139-149.

Katz, Steven, 1992, "Mystical Speech and Mystical Meaning", i: S. Katz (ed.), Mysticism and Language, New York, 3-41.

Kippenberg, Hans, 1970, "Versuch einer soziologischen Verortung des antiken Gnostizismus", i: Numen, Vol. 17, 211-231.

Kuyt, Annelies, 1990, "Once Again: Yarad in Hekhalot Literature", i: Frankfurter Judaistische Beiträge, 18, 45-69.

Montgomery, James A., 1913, Aramaic Incantation Texts from Nippur, Philadelphia.

Naveh, Joseph \& Shaul Shaked, 1985, Amulets and Magic Bowls: Aramaic Incantations of Late Antiquity, Jerusalem.

-, 1993, Magic Spells and Formulae: Aramaic Incantations of Late Antiquity, Jerusalem.

Otzen, Benedikt, 1984, Den antike jødedom, Viborg.

Preisendanz, Karl, 1928/31, Papyri Graecae Magicae, Vol. I-II, Leipzig-Berlin.

Rudolph, Kurt, 1977, “Das Problem einer Soziologie und 'sozialen Verortung' der Gnosis”, i: Kairos, 19/1, 35-44.

Schäfer, Peter (Hrsg.), 1981, Synopse zur Hekhalot-Literatur, Tübingen.

-, 1984, Geniza-Fragmente zur Hekhalot-Literatur, Tübingen.

-, 1988, Hekhalot-Studien, Tübingen.

Schiffman, Lawrence H., 1982, "Merkavah Speculation at Qumran: The 4Q Serekh Shirot 'Olat haShabbat”, i: J. Reinharz \& D. Swetschinski (eds.), Mystics, Philosophers, and Politicians. Essays in Jewish Intellectual History in Honor of Alexander Altmann, Durham, 15-47.

Schiffman, Lawrence H. \& Michael D. Swartz, 1992, Hebrew and Aramaic Incantation Texts from the Cairo Geniza, Sheffield.

Scholem, Gershom G., 1961, Major Trends in Jewish Mysticism, New York.

-, 1962, Ursprung und Anfänge der Kabbala, Berlin.

-, 1965, Jewish Gnosticism, Merkabah Mysticism, and Talmudic Tradition, New York.

-, 1977, Von der mystischen Gestalt der Gottheit, Frankfurt a. Main.

Smith, Morton, 1978, Jesus the Magician, New York.

Strugnell, John, 1960, "The Angelic Liturgy at Qumran - 4Q Serek Sirot 'Olat Hassabbat", i: Supplements to Vetus Testamentum, Vol. II, 318-345. 
Swartz, Michael D., 1992, Mystical Prayer in Ancient Judaism, Tübingen.

Urbach, Efraim E., 1975, The Sages, Jerusalem.

\section{Summary}

The aim of the article is to show how early Jewish mystics made a new interpretation of the tradition, i.e. the theology of their time and by doing so, they went far off their orthodox traditon. For many years the questions of when and from where did the Merkavah Mysticism develop have been a subject of discussion among researchers in Rabbinic Judaism. In fact, we still do not know the exact time neither the locus, a quo and we may perhaps never know, but this shall not prevent us from asking the traditional questions about the emergence.

As we all know Sholem did a tremendous effort to make Jewish mysticism salonfähig for the academic circles, and his achievement can not be overestimated, but unfortunately he was not very precise in his definitions, which sometimes made some of his writings a little bit vague. After some critical remarks on Scholem I look historically at some of the main topics on early Jewish mysticism, and in my survey I include researchers like Ithamar Gruenwald, David Halperin, Lawrence Schiffman and Peter Schäfer. Halperin, especially, has focused on the question of recruitment of adepts/mystics and he argues, that the people behind the Merkavah mysticism came from the עם האר ה.e. i.e. the people of the land. But this is still a problem, and for the time being I do not agree with Halperin on that.

In the main section of the article I focuse on two of the so-called makroforms, i.e. longer rather homogenous passages of texts, which is called Hekhalot Zutarti and $\mathrm{Ma}$ 'aseh Merkavah. In those texts we find a lot of magical statements and if we compare this to the traditional view of God at that time (about 200-600 C.E.), we can hardly deny that at least some of the mystics moved behind the limit of orthodoxy, or - shoul we say - the theology of tradition. But that does not necessarily force us to give up the view that at least some of the mystics could have belonged to rabbinic circles - this is still an open question. 